\title{
C-Type Lectin-HIV Attachment on Dendritic Cells:Innate Immune Recognition and Processing or Mediators of HIV Transmission?
}

\author{
樹状細胞表面におけるC型レクチンとHIVとの結合：先天性免疫による認識とプロセシングか \\ HIV伝播の介在因子か
}

\author{
Turville, Stuart G' ; Cameron, Paul $\mathbf{U}^{2}$; Hart, Derek ${ }^{3}$; and Cunningham, Anthony $\mathrm{L}^{1}$ \\ ${ }^{1}$ Center for Virus Research, Westmead Millennium Institute, Westmead Hospital and University of Sydney, Sydney, NSW 2145, \\ Australia. Australian National Centre for HIV Virology Research. \\ ${ }^{2}$ Department of Microbiology and Immunology, University of Melbourne, Parkville,Victoria, Australia 3052 \\ ${ }^{3}$ Mater Medical Research Institute, Mater Hospital, Brisbane, Queensland, Australia. \\ Westmead Millennium Institute, PO Box 412, Darcy Road, Westmead, NSW 2145, Australia. \\ FAX: +61-2-9845-9100, E-mail: Tony_cunningham@wmi.usyd.edu.au
}

Key Words : HIV gp120, langerin, mannose receptor, DC-SIGN, CD4

\begin{abstract}
Dendritic cells (DC) provide a bridge between the innate and acquired immune system. HIV exploits the complex pathways of microbial antigen uptake and transport by these cells for initial entry and dissemination. Within DCs, some HIV escapes endolysosomal degradation and antigen presentation pathway to be transferred to $\mathrm{CD}^{+}$lymphocytes during activation of $\mathrm{T}$ cell-mediated immunity. In skin DC the $\mathrm{C}$ type lectin receptors (CLRs), langerin on Langerhans cells (LC), and DCSIGN and mannose receptor (MR) on dermal DC subsets are all capable of binding HIV gp120 through its mannose saccharides. Among DCs only the immature DCs in the periphery can bind HIV through CLRs and this enhances HIV fusion with the target cell membrane via $\mathrm{CD} 4 /$ chemokine receptors, or mediates entry into the endolysosomal pathway. Although CLR transfected cell lines and CLR expressing monocyte derived DC (MoDC) can transfer HIV independent of fusion in vitro, observations of DC ex vivo or in vivo show that CLR-enhanced CD4/CCR5mediated viral fusion appears to be necessary for viral transfer to $\mathrm{T}$ cells. Thus HIV utilizes recognition of abundant high mannose glycans on its envelope protein, for binding to CLRs on skin and mucosal DCs, entry via CD4/CCR5 and transport by DCs to $\mathrm{CD}^{+}$lymphocytes in lymph nodes, the major site of viral replication.
\end{abstract}

要 約

樹状細胞 (DC) は先天性免疫システムと獲得免疫システムの 橋渡しをする細胞である。HIVはこれらの細胞による微生物抗 原の取り込みや複雑な輸送経路を利用して初期感染と播種を 行っている。 $\mathrm{T}$ 細胞介在性免疫反応が活性化する際 DC から CD4陽性リンパ球へ抗原提示情報が伝えられるが、HIV の一部 は DC 内部のエンドリソゾーム分解経路やこの抗原提示経路を 回避する。皮膚の DC のうちランゲルハンス細胞 $(\mathrm{LC})$ に発現す る langerin、真皮 DC 亜集団に発現する DC-SIGN やマンノース 受容体 (MR) といった C 型レクチン受容体 (CLRs) はすべてマ ンノース糖鎖を介して HIV gp120 と結合することができる。DC のうち末梢に存在する未成熟 DC のみが CLRsを介して HIV と 結合できる。この結合が $\mathrm{CD} 4 /$ /ケカイン受容体を介した標的 細胞膜と HIV との融合を促進し、あるいはエンドリソゾーム経 路への移行を仲介する。CLR を遺伝子導入した細胞株や CLR を 発現する単球由来 DC (MoDC) は in vitro において融合に依存せ ずに HIV を運搬できるが、 ex vivo あるいは in vivoでの DC の観 察結果から CLR が促進する CD4/CCR5 介在性のウイルス融合 が T細胞へのウイルス感染に必要であることがわかった。すな わち皮膚や粘膜 DC 上の CLRs との結合、CD4/CCR5 を介する 侵入、またウイルス複製の主要な場であるリンパ節内において DC から CD4 陽性リンパ球へウイルスを運搬するために、HIV は自身のエンベロープタンパク質に豊富に存在する高マンノー ス型糖鎖に対する DC の認識機構を利用している。

\section{A. Function of DCs In Vivo}

DC represent discrete leukocyte populations, that are found in both non-lymphoid and lymphoid tissue and perform their functions by migration between the two (1). DCs also have the capacity to link the innate and acquired immune response

\section{A. In Vivoにおける樹状細胞の機能}

樹状細胞 (DC) はいくつかの別々の白血球集団の総称である が、いずれも非リンパ系組織とリンパ系組織のどちらにも存在 し、両組織間を移動することでその機能を発揮する(1)。DC は さらに先天性免疫応答と獲得免疫応答を結びつける機能をも 
and the unique capability to stimulate primary $\mathrm{T}$ cell-mediated immunity (1-3). In their "immature," state, DC carry out the sentinel function of the innate immune response by efficiently capturing and processing antigens in peripheral non-lymphoid tissue and forming MHC II peptide complexes, but provide little costimulation for T cells (2). Upon antigenic exposure and with other accompanying danger signals, the immature DC "mature," and migrate via the lymphatics to lymphoid tissue, thus increasing the probability of interacting and stimulating the appropriate primary $\mathrm{T}$ lymphocyte response.

DC populations can be sub-divided into three functional subsets: i) precursor DC, ii) immature DC and iii) mature DC (Fig. 1). Precursor DC differ from classic immature and mature DC, as they can rapidly assume either the phenotype of immature or mature DC, under appropriate in vitro or in vivo condi-
ち、 $\mathrm{T}$ 細胞介在性の一次免疫応答を活性化するという特徵的な 機能を有している(1-3)。“未成熟”な状態の DC は末梢の非リン パ系組織に抢いて効果的に抗原を捕捉、分解し、MHC II 分子と ペプチドの複合体を形成することによって先天性免疫応答にお ける見張りの役割を果たしている。この状態では $\mathrm{T}$ 細胞へ共刺 激を与えることはほとんどない(2)。抗原に加えて付随する危険 シグナルを受けることにより未成熟 DC は“成熟”する。成熟 DC はリンパ管を経てリンパ系組織に移動し、Tリンパ球の一 次応答を活性化する可能性を増大させる。

DC は 3 つの機能的な亜集団に分けることができる：i) DC 前駆細胞、ii) 未成熟DC とiii) 成熟 DC (図 1)である。未成熟 DC や成熟 DCについては in vivo あるいは in vitro の特定の条件下 でその表現型を簡単に判定することができる。一方、DC 前駆 細胞は従来から言われていた未成熟 DC や成熟 DC とは異なる

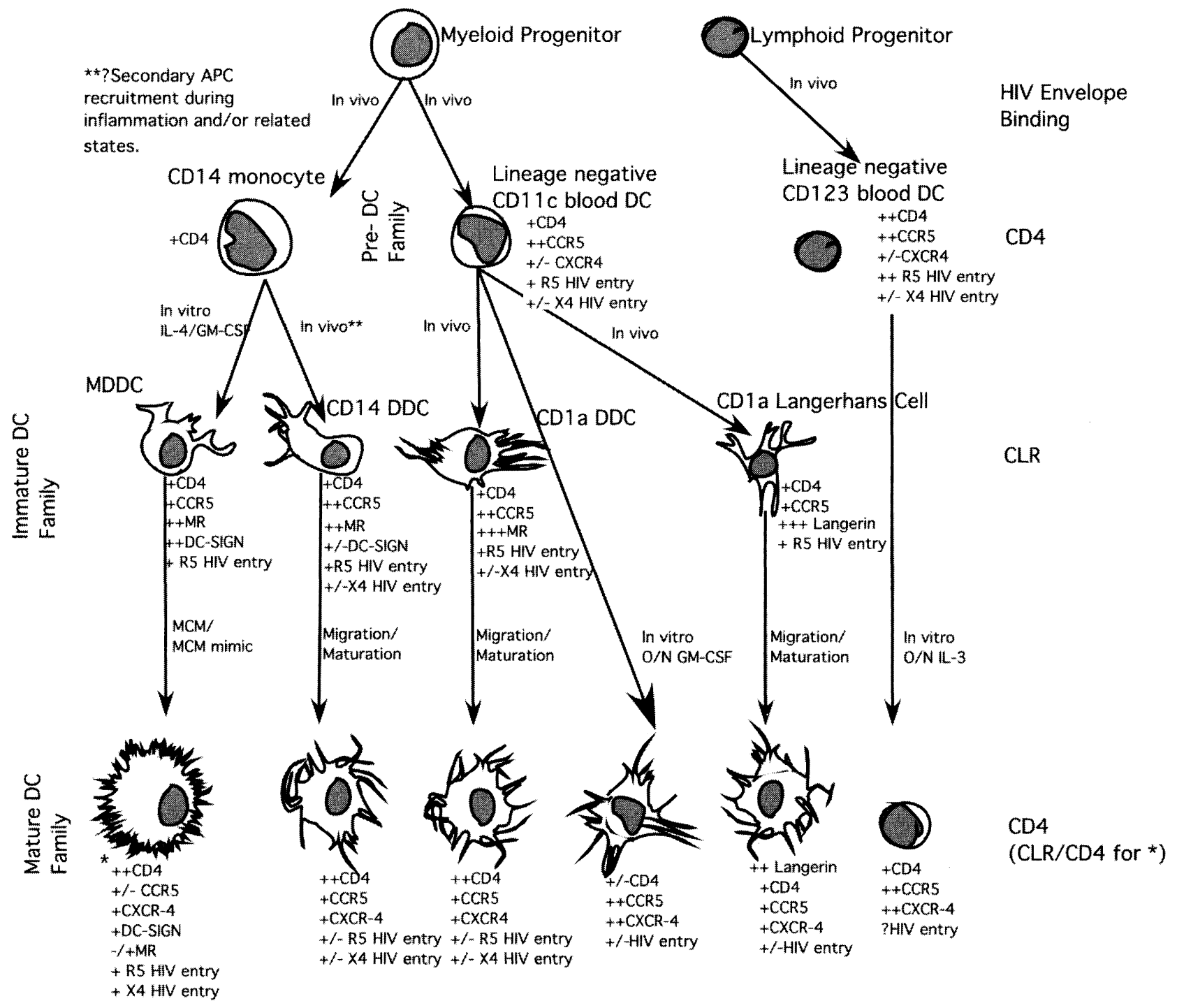

Fig. 1. DC diversity, HIV receptors and evidence for HIV viral fusion. Relative expression of CD4, CCR5, CXCR4, MR, DC-SIGN and langerin are indicated for the three broad DC subdivisions: Precursor DC, immature and mature DC. Evidence for CCR5 (R5 isolates) and CXCR4 utilising HIV-1 (X4 isolates) infection are also presented. HIV gp120 binding phenotype for each group is presented on the far right. 
tions. Precursor DC can be identified in blood and/or lymphoid tissue as "lineage negative" cells defined by the lack of the surface markers CD3, CD14, CD11b, CD16 and CD19 and expression of moderate to high HLA-DR (3). Two subsets of precursor DC can be further identified by expression of either $\mathrm{CD} 11 \mathrm{c}$ or CD123. The so called lymphoid or $\mathrm{CD} 123^{+}$subset distinguished by the utility to produce IFN- $\alpha$ is thought to migrate directly via the high endothelial venule into the $\mathrm{T}$ cell area of lymph nodes (4). Immature tissue DCs represent an extensive network in almost every tissue type throughout the body. LCs are the best studied example and are located within the basal and suprabasal layers of the epidermis $(5,6)$. Phenotypically LCs are characterized by the high expression of the CD1a antigen, the presence of Birbeck granules (trilaminar cytoplasmic structures visible by electron microscopy) and more recently the expression of the type II CLR langerin (7). Deep to the epidermis, are the diverse and widely distributed interstitial DCs exemplified by the dermal DC. They differ functionally from LC, in their variable expression of CD1a and lack of Birbeck granules $(3,8-10)$. Two main dermal DC subsets have been previously identified as $\mathrm{CD} 14^{+} \mathrm{CD} 1 \mathrm{a}^{ \pm}$or $\mathrm{CD} 14 \mathrm{CD}^{\mathrm{C}} \mathrm{a}^{+}(10$ 12). Recently these two subsets have also been distinguished by differential DC-SIGN expression in fresh dermal preparations as $\mathrm{CD} 14^{+} \mathrm{CD} 1 \mathrm{a}^{ \pm} \mathrm{DC}-\mathrm{SIGN}{ }^{+}$or CD14-CD1a ${ }^{+} \mathrm{DC}-\mathrm{SIGN}^{-}$(12) (Fig. 1). These DC subsets differentiate into their mature counterparts either during migration and/or in response to local tissue insult or microbial invasion. The transition from immature to mature DC, results in down regulation of the mechanisms of antigen uptake, including CLRs, complement and Fc receptors and macropinocytosis, but upregulation of cell surface MHC adhesion and costimulatory molecules which assist in molecular adhesion to and activation of $\mathrm{T}$ lymphocytes (reviewed in (8)).

As DC are rare in blood, and difficult to isolate from tissues, several in vitro DC models have been developed to enable characterization of DC. The most commonly used DC is derived from peripheral blood monocytes, MoDC, by stimulation with IL-4 and GM-CSF $(13,14)$. Although MoDC are believed to resemble a dermal DC subset in vivo, phenotypically they are quite distinct and really should be considered a unique in vitro $\mathrm{DC}$ phenotype. Maturation of MoDC can be achieved using microbial products such as LPS or combinations of proinflammatory stimuli like TNF $\alpha, \mathrm{IL}-6, \mathrm{IL}-1 \beta$ and $\mathrm{PGE}_{2}$ (15) or monocyte conditioned media.

Other in vitro models are available that may represent DC subsets in vivo. A model of mature DC has also been developed using skin explant cultures $(9,10)$, given immature DC have the ability to mature during migration from epidermal and dermal split skin sections over 1 to 3 days in culture. Commonly referred to as "emigrant DC," they resemble mature T cell stimulatory DC that are found actively migrating into drain-
細胞集団である。DC 前駆細胞は血液中もしくはリンパ系組織中 で “lineage negative” の細胞集団として、すなわち表面マーカー である CD3、CD14、CD11b、CD16、そして CD19を欠き、 HLA-DR を中発現あるいは高発現する細胞集団として同定され る(3)。DC 前駆細胞 はさらに CD11c や CD123 の発現の有無に より二つの亜集団に分類できる。IFN- $\alpha$ 産生能を有するいわゆる リンパ系 DCもしくは CD123+DC 亜集団は、高内皮細静脈を経 てリンパ節の T 細胞領域に直接移動すると考えられている(4)。 組織に存在する未成熟 DC は体内のほとんどすべての組織で大 規模なネットワークを張り巡らせている。ランゲルハンス細胞 (LC)については最もよく研究されている。この細胞は表皮の基 底層および基底上層に存在する(5、6)。LC の表現型はCD1a 抗原 の高発現、Birbeck 顆粒の存在（電子顕微鏡で 3 層の細胞質構造 物として観察される）、また最近は II 型のC 型レクチンである langerinの発現により特徵づけられている(7)。表皮よりもさらに 深部には、多様で広範に分布する真皮 DC などの間質性の DC が 存在する。これらの細胞は CD1a 発現頻度が様々である点と Birbeck 顆粒を欠く点で LC とは機能的に異なっている $(3,8-10)$ 。 真皮 DCのうち主要な亜集団としてCD14 ${ }^{+} \mathrm{CD} 1 \mathrm{a}^{ \pm}$とCD14 $\mathrm{CD}^{-} \mathrm{a}^{+}$ の 2 つが同定されていた(10-12)。最近、真皮から調製した $2 つ$ の亜集団で DC-SIGN の発現が異なること、すなわち両者が $\mathrm{CD}_{14}{ }^{+} \mathrm{CD} 1 \mathrm{a}^{ \pm} \mathrm{DC}-\mathrm{SIGN}{ }^{+}$とCD14-CD1a ${ }^{+}$DC-SIGN-として区別され ることが示された(12)(図 1)。これらの DC 亚集団は遊走過程、 局所組織損傷や微生物侵入に応答して成熟 DCに分化する。未 成熟 DC から成熟 DCへ分化すると C 型レクチン受容体 (CLRs)、 補体受容体、 $\mathrm{Fc}$ 受容体依存的な抗原取り込み機構やマクロピノ サイトーシスが抑制される。一方 Tリンパ球への接着や活性化 を補助する MHC 分子と共刺激分子の細胞表面発現は増強される （総説 (8) を参照）。

DC が血液中にほとんど存在せずまた組織からの単離が困難 であるため、DC の性状解析を可能にするために in vitro の DC モデルがいくつか開発されている。最も一般に用いられている DC は MoDC と呼ばれる末梢血単球由来の DCで、これはIL-4 とGM-CSF で単球を刺激することによって得られる(13、14)。こ のMoDC は in vivo に扔いて真皮未成熟 DC の亜集団に類似して いると信じられているが、本来両者は別々であり、独特なin vitro の DC 表現型をもつものと考えるべきである。MoDC の成熟化

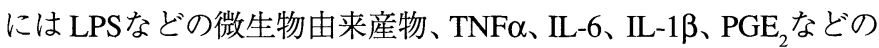
炎症性刺激の組み合わせ $(15)$ や単球の培養上清が用いられる。

In vivo における DC 亜集団の性質を表現する in vitro のモデ ルは他にもある。皮膚移植片の培養によって成熟 DC のモデル が開発された $(9 、 10)$ 。表皮と真皮に分けられた皮膚切片から未成 熟 DC が游走するとき、培養1３日間で成熟化することがわかっ た。これは一般に “emigrant DC”と呼ばれており、自ら所属リン パ管(16)からリンパ節に遊走し(17) T 細胞を刺激する細胞として 
ing lymphatics (16) and subsequently into the lymph node (17).

\section{B. DC Subsets and HIV Infection In Vivo}

The DC is believed to play a major role in HIV pathogenesis. In animal models, simian immunodeficiency virus (SIV) is detected within intraepithelial DC and lamina propria DC $(18,19)$ early after viral vaginal inoculation. In skin and mucosa of seropositive patients, LCs were observed to harbor HIV or support viral replication of the virus in vitro (20-26) (Cimarelli et al, (21) estimates at least $3 \%$ of LC harbour HIV proviral DNA). In seropositive asymptomatic women, one third of vaginal biopsies demonstrated HIV-positive LC in the vaginal epidermis, whereas in the lamina propria HIV-positive lymphocytes and DCs (at -1:1) were detected in three-quarters of the biopsies (20). Active replication of HIV-1 was also observed within lymphoepithelia of lymphoid tissue and was associated with syncytia containing DC markers $(27,28)$, indicating a key role for DCs in HIV-1 replication, especially early in infection (27). These are supported by in vitro observations of HIV infected DC-CD4 $4^{+}$lymphocyte co-cultures. HIV infection results in syncytium formation between DC and multiple bound T lymphocytes, in addition to viral production greater than that of any individual cell population $(29,30)$. Such HIV or SIV transfer from $\mathrm{DC}$ to $\mathrm{CD}^{+}$lymphocyte occurs predominantly in the lymph node but may also occur within DC-T cell clusters in skin or mucosa.

Thus in vivo, DC participate in several aspects of HIV pathogenesis. In animal studies DC have also been shown to play a key role in HIV transmission. Hence the molecular mechanisms of HIV binding and infection of DC are of immense interest. The CD4 and chemokine receptors have been extensively studied on DC (32-35). Both in vitro and in vivo data shows HIV enters via viral fusion (12,21-25,30-49). Immature DC, resident in the epithelia, are able to bind a variety of microbial antigens via a range of specialized receptors including CLRs and the Toll-like receptors. It is not surprising that at least some of these relevant innate receptors can also bind HIV.

\section{First Contact: HIV Attachment to DCs:}

\section{C-1. CD4 and Chemokine Receptors; Viral Fusion and Evi- dence for HIV Infection of DC.}

The process of retroviral entry into the major cellular targets, $\mathrm{CD} 4^{+}$lymphocytes and macrophages, is a cascade of events initiated by the attachment of the viral surface glycoproteins to specific cell receptors, culminating in the fusion of cell and viral lipid bilayers and deposition of viral RNA, replicative enzymes and proteins involved in transport to the nucleus into the cytoplasm (see (50) for review of fusion based entry and nuclear import). The envelope glycoprotein of HIV responsible for mediating cellular binding and priming the fusion process is gp120. HIV gp120 is noncovalently associated to the transmem-
見出された成熟 DC に類似している。

\section{B. In Vivo での DC 亜集団と HIV 感染}

DC は HIV 感染において主要な役割を担っていると考えら れている。動物モデルでは、ウイルスを胵内接種するとその直 後にサル免疫不全ウイルス (SIV) が上皮内および粘膜固有層の DC で検出された $(18 、 19)$ 。血清反応陽性の患者の皮膚や粘膜で は、LCがHIVを保持し in vitro でのウイルス複製を補助するこ とが観察された(20-26)（Cimarelli ら(21)は少なくとも $3 \%$ の LC が HIV プロウイルスの DNA を保持しているものと予測してい る）。血清反応陽性で無症候の女性では、腔生検で臸表皮に HIV 陽性の LC が観察されたのは 3 例に 1 例の割合であった。 一方、HIV 陽性の患者では粘膜固有層リンパ球と DC（約 1:1） が検出されたのは 4 例に 3 例の割合であった(20)。リンパ系組織 内のリンパ上皮でHIV-1 の活発な複製が観察され、これはDC マーカーを含む多核巨細胞（細胞融合の結果生じたもの）の存 在と相関していた $(27 、 28)$ 。このことから DC が特に感染初期の HIV-1 複製に重要な役割を果たしていることが示唆された(27)。 以上のことは in vitro での HIV 感染 DC と CD4 陽性リンパ球と の共培養結果からも支持されている。共培養時には個々の細胞 によるウイルス産生よりも多くのウイルスが産生されるが、そ れに加えてHIV 感染により DCとここに多数結合したTリンパ 球との間で多核巨細胞が形成される(29、30)。HIV や SIV が DC から CD4 陽性リンパ球へ輸送されるのは主にリンパ節で起こる が、皮膚や粘膜における DC-T 細胞クラスターでも同様のこと が起きているのかもしれない。

以上のように、DC は in vivo で HIV 感染のいくつかの局面 に介在している。動物実験ではDCが HIV の伝播においても重 要な役割を果たしていることがわかっている。したがって HIV の DCへの結合や感染の分子機構は非常に興味深い。DCに発 現するCD4 やケモカイン受容体については広く調べられている (32-35)。in vitro、in vivo の結果はともに HIV がウイルス融合 によって侵入することを示している(12、21-25、30-49)。上皮に存 在する 未成熟 DC は C 型レクチン受容体 (CLRs) や Toll-like 受 容体を含む特殊な受容体で様々な微生物抗原と結合することが できる。このいくつかがHIV と結合できたとしても不思議では ない。

\section{C. 最初の接触：DCへの HIV の吸着 :}

C-1. CD4 とケモカイン受容体； ウイルスの融合と HIV が DC に感染する根拠

レトロウイルスがその主要な標的細胞である CD4 陽性リン パ球とマクロファージへ侵入する経路は、まずウイルス表面糖 タンパク質と細胞上の特異的受容体の結合に始まり、続いて細 胞とウイルスの脂質二重膜の融合、さらにウイルス RNA、複製 酵素や核移行に関わるタンパク質が細胞質に送り込まれる、と いう事象のカスケードである（融合による移入と核移行につい ては(50)を参照）。細胞への結合と融合過程の開始に関与する HIV 上のエンベロープ糖タンパク質は gp120である。HIV の gp120 は膜貫通領域を有する糖タンパク質である gp41 と非共有 
brane domain glycoprotein, gp 41 , each as a trimer $(51,52)$.

CD4 is the primary receptor which binds HIV gp120 to $\mathrm{CD}^{+}$lymphocytes and CD4 expressing cells of the myeloid lineage. Following binding to CD4, gp120 undergoes conformational change and then binds to one of the chemokine receptors, usually CXCR4 and CCR5, which then results in exposure of the fusion peptide in the viral transmembrane protein gp41, which mediates HIV-cell membrane fusion (53-55). Chemokine receptor restricted entry divides HIV isolates functionally into either R5 (CCR5 utilizing) or X4 (CXCR4 utilizing) strains (56). However R5 strains are detected predominantly in early stages of disease (57), X4 strains are usually found in immunosuppressed patients (58). Viral binding to DC must be considered separately for each subset in the immature and mature state. Although the majority of DC express relatively low levels of CD4, expression of either CCR5 or CXCR4 can vary markedly. The controversy regarding HIV infection of DC is linked to this low level of CD4/CCR5 expression. DCs, in contrast to activated $\mathrm{CD}^{+} \mathrm{T}$ lymphocytes, do not produce large quantities of virus (i.e. productive infection). In addition, when DCs attain their mature phenotype, viral production is further reduced, because of a post-integration block, mainly at the transcriptional level (59). The expression of CD4, CXCR4 and CCR5, in addition to evidence of viral fusion through proviral DNA integration in DCs are presented and summarized in Figure 1.

\section{C-2. Alternate HIV Binding Receptors: HIV CD4-Indepen- dent Viral Attachment}

Attachment of HIV gp120 or virus to the cell surface by receptors, other than CD4, may increase the cell surface concentration of HIV, increasing the likelihood of infection of each cell (60). Cell membrane receptors such as the host cell derived receptors, heparan sulfates and CLRs, may play a crucial role where CD4 and/or chemokine receptor expression is limiting. In this review we will focus on CLRs as specific attachment factors for HIV (see (61) for review of other mechanisms of HIV attachment).

\section{HIV Envelope Glycosylation and C-type Lectin Binding}

Approximately $50 \%$ of the apparent molecular weight of HIV gp120 consists of oligosaccharides (62). This extensive glycosylation is believed to assist in evasion of the humoral response, as removal of key glycosylation sites in the SIV gp130 augments the humoral immune response in vivo (63). Studies using mammalian cell expressed gp120 from the HIV isolate IIIb, demonstrate $24 \mathrm{~N}$-linked glycosylation sites. Of the 24,13 contain complex oligosaccharides and the remaining primarily hybrid and/or high mannose structures (62). From mass spectrometric analyses of glycosylation sites and structural modeling, the high mannose glycans appear to cluster together on the surface, whereas the complex glycans form another cluster with little structural overlap (64). Recently HIV produced by mac-
結合で会合し、それぞれ 3 量体として存在している $(51 、 52) 。$

CD4 は HIVの gp120 と CD4陽性リンパ球や骨髄系の CD4 発現細胞との結合を引き起こすための主要な受容体である。 gp120 は CD4 と結合した後に構造変化を起こし、ケモカイン受 容体のどれか一つ（通常 CXCR4 もしくはCCR5）と結合し、そ の結果ウイルスの膜貫通タンパク質 gp41 の融合ペプチド部が露 出され、HIV と細胞との膜融合が起こる(53-55)。HIVはそのケ モカイン受容体の拘束性から R5 (CCR5 を利用する) 株、X4 (CXCR4 を利用する)株のいずれかに分類できる(56)。R5 株が主 に疾患の初期段階で検出される(57)のに対し、X4 株は通常、免 疫抑制状態の患者で検出される(58)。各 DC 亜集団に対するウイ ルス結合は未成熟状態と成熟状態に分けて考えなければならな い。DC の大多数は CD4 の発現量が低いが CCR5 あるいは CXCR4 の発現量は様々である。DCへの HIV 感染で議論となっ ているのはこの CD4/CCR5 が低発現であることにある。活性化 $\mathrm{CD} 4$ 陽性 Tリンパ球とは対照的に DC は大量のウイルスを産生 しない(増殖性感染をしない)。さらに DC が成熟状態にある時 は、ウイルス組込み後に主に転写レベルで抑制がかかるためウ イルス産生はさらに減少する(59)。DC 亜集団におけるプロウイ ルス DNA の宿主染色体への組み込みを介したウイルス融合の 有無、CD4、CXCR4 や CCR5 の発現の有無を図 1にまとめた。 C-2. 他の HIV 結合性受容体：CD4 非依存的な HIV 結合

CD4 以外の分子を介してHIV gp120 あるいはウイルスが細 胞表面に結合すると、細胞表面上の HIV 濃度が上昇して細胞へ の感染が成立しやすくなると考えられる(60)。CD4 やケモカイ ン受容体の発現が限られている際には、宿主細胞由来の受容 体、ヘパラン硫酸、CLRs などの細胞膜受容体が重要な働きをし ているのであろう。この総説では CLRs を HIV に特異的に結合 する因子として取り上げる（他の HIV 結合機構については総説 (61)を参照)。

D. HIV エンベロープの糖鎖修飾と C 型レクチンとの結合

HIV gp120 の分子量のうち、そのおよそ50\%はオリゴ糖の 分である(62)。サル免疫不全ウイルス (SIV) gp130 から鍵になる 糖鎖付加部位を除くとin vivoに予ける体液性免疫応答が増大寸 ることから、この高密度の糖鎖修飾は体液性免疫応答からの回 避に役立っていると考えられている(63)。HIV IIIb の gp120を 発現させた哺乳動物細胞を用いた研究では、 $N$-結合型糖鎖の付 加位置が 24ヶ所存在することが明らかになっている。このうち 13ヶ所は複合型糖鎖を有しており、残りはハイブリッド型もし くは高マンノース型糖鎖を有していた $(62) 。$ 糖鎖付加位置のマス スペクトル解析と構造モデル解析により、高マンノース糖鎖は 表面でクラスターを形成している一方、複合型糖鎖はこれとは 重ならないように別のクラスターを形成していた(64)。最近に なってマクロファージの産生する HIV の複合型糖鎖には T 細 
rophages has been shown to express more $\mathrm{N}$-acetyllactosamine repeats on complex glycan chains, thus resulting in a higher degree of heterogeneity in glycosylation compared to $\mathrm{T}$ cell derived HIV (65-67). Although these may facilitate evasion of the humoral response they are still targets of the innate immune system via C-type lectins (CLs).

The characteristic structural and functional features of the CL family are the conserved carbohydrate recognition domains (CRDs) that bind carbohydrates in a calcium dependent manner. The CL family includes a number of structurally diverse molecules. The MR; (CD206) family are type I transmembrane proteins containing 8 CRDs, of which 4-8 are required for binding mannose, $\mathrm{N}$-acetylglucosamine or fucose terminated ligands. The DC-SIGN (CD209) and DC-SIGNR family are type II transmembrane proteins that have a small cytoplasmic domain at their $\mathrm{N}$-terminus, a transmembrane domain and a large extracellular single CRD at the C-terminus. There is also a neck domain between the TM and CRD which mediates oligomerization. Like DC-SIGN and DC-SIGNR, langerin (CD207) is a type II transmembrane protein with a single external CRD. DEC205 has been shown to have a different tissue distribution to MR and is extremely efficient at directing antigen into class II process pathways.

Ligand specificity also differs amongst these CLs. Mannose binding proteins preferentially bind to oligosaccharides, on pathogens rather than the host cell surface, binding to single terminal mannose or $N$-acetylglucosamine residues, usually in dense arrays on the pathogen cell surface. However, DC-SIGN and DC-SIGNR bind with high affinity to the outer trimannose branch structures on high mannoses oligosaccharides of mammalian as well as the pathogen cell surface, especially on $T$ cells and in HIV envelope proteins (68). MR is postulated to be a clearance molecule for microbes, with subsequent antigen uptake and presentation by antigen presenting cells, like DC and macrophages $(69,70)$. DC-SIGN has also recently been suggested to have a similar role to MR in antigen acquisition and processing, especially in DCs and perhaps also macrophages $(12,71,72)$. One common feature of all of the above CLR is they show binding to HIV via the saccharides on HIV gp120 (12,73-76). However HIV gp120 binding to such CLR is dependent on the host cell from which HIV is produced. HIV produced from T lymphocytes but not macrophages has been shown to bind DC-SIGN and DC-SIGNR (66). The presence of $N$-acetyllactosamine repeats on macrophage-derived HIV, appears to hinder effective HIV gp120 attachment to these CLR (66). Although these lectins are designed for clearance of viruses and viral antigen uptake from the tissues, they may also facilitate binding and entry of HIV into DCs and therefore HIV transmission during mucosal exposure.

Serum mannose binding proteins (MBP) are members of the collectin family, multimeric lectins consisting of four
胞由来の HIV と比較してN-アセチルラクトサミン構造の繰り返 しがより多く、そのため糖鎖構造がより不均一であることがわ かった(65-67)。このことは体液性免疫からの回避を可能にする かもしれないが、一方でこれは C 型レクチン(CLs) を介する先 天性免疫の標的となるものである。

C 型レクチンファミリーの特徵的な構造は、糖鎖との結合 にカルシウムを要求する保存された糖鎖認識部位 (CRD) を有す ることである。C 型レクチンファミリーは構造的に多様な分子 から成る。マンノース受容体 (MR；CD206) ファミリーはI 型 膜貫通型タンパク質で 8 つの CRD をもち、そのうち $4 \sim 8$ 個は 末端がマンノース、 $N$-アセチルグルコサミン、フコースで修飾 されたリガンドとの結合に必要である。DC-SIGN (CD209) と DC-SIGNR ファミリーは II 型膜貫通型タンパク質であり、N末 端の短い細胞内領域、膜貫通領域と $\mathrm{C}$ 末端の細胞外領域に大き な CRDを1つ有している。また膜貫通領域と CRD の間には多 量体形成に必要なネック領域も有している。DC-SIGN や DCSIGNR と同様に langerin (CD207) は II 型膜貫通型タンパク質で 細胞外領域に 1 つの CRD を有している。DEC-205 は MR とは 異なる組織分布を示し、class II の経路に極めて効果的に抗原を 運搬する。

これらのC 型レクチンはその基質特異性も異なっている。 マンノース結合タンパク質は、通常、病原体の細胞表面に密に 存在する末端のマンノース残基や $N$-アセチルグルコサミン残基 に結合する。これは宿主細胞表面ではなく病原体に発現するも のである。一方、DC-SIGN や DC-SIGNR は病原菌の細胞表面 だけでなく哺乳類にも存在する（特にT 細胞や HIV エンベロー プタンパク質に存在する）高マンノース型オリゴ糖末端の tri-マ ンノース分岐構造に対して高い親和性をもつ(68)。MR は微生物 を排除する分子であり、さらにDC やマクロファージといった 抗原提示細胞による抗原取り込みと抗原提示に関与すると考え られている(69、70)。DC-SIGN は DC や拈そらくマクロファージ に扔ける抗原の獲得とプロセシングについて、MRと同様の役割 をしていることが最近示されてきている $(12 、 71 、 72)$ 。上述の CLR すべてに共通するのは、これらがすべて HIV gp120 上の糖 鎖を介して HIV に結合するということである(12、73-76)。しか し、HIV gp120 と CLR との結合が生ずるかどうかは、どの宿主 細胞から HIV が産生されたかということに依存する。Tリンパ 球から産生された HIV はDC-SIGN と DC-SIGNR に結合するが、 マクロファージから産生された HIVではそのような現象は生じ ない(66)。マクロファージ由来の HIVにはアセチルラクトサミ ンの繰り返し構造が存在し、これがレクチンに対する HIV gp120 の結合を妨げている(68)。これらのレクチンはウイルスや組織か ら取り込まれたウイルス抗原を除去するために設計されている が、同時にDCへの HIV の結合と侵入を促進する。そのため HIV が粘膜に曝される間に HIV の伝播が成立するのであろう。

血清中のマンノース結合タンパク質(MBP)はコレクチン ファミリーに属し、 $\mathrm{N}$ 末端にシステインに富む領域、コラーゲ 
Table I. Structure of C-type lectins in HIV binding to DCs.

\begin{tabular}{|c|c|c|l|c|}
\hline Family & Type of Protein & $\begin{array}{c}\text { Oligomerization } \\
\text { Status }\end{array}$ & \multicolumn{1}{|c|}{$\begin{array}{c}\text { Domain } \\
\text { Structure (N-C) }\end{array}$} & $\begin{array}{c}\text { Member of } \\
\text { CRDs per Monomer }\end{array}$ \\
\hline $\begin{array}{c}\text { mannose } \\
\text { binding protein }\end{array}$ & Soluble & hexamer & $\begin{array}{l}\text { (Cys-rich)-(collagen-like)- } \\
\text { (neck-CRD) }\end{array}$ & 1 \\
\hline MR & $\begin{array}{c}\text { Type I } \\
\text { transmembrane }\end{array}$ & trimer & $\begin{array}{l}\text { (Cys-rich)-(fibronectin type II)- } \\
\text { (CRDs)-(TM)-(cytoplasmic) }\end{array}$ & $\begin{array}{c}9(4 \text { are CHO } \\
\text { binding) }\end{array}$ \\
\hline $\begin{array}{c}\text { DC-SIGN } \\
\text { DC-SIGNR }\end{array}$ & $\begin{array}{c}\text { Type II } \\
\text { transmembrane }\end{array}$ & trimer & (cytoplasmic)-(TM)-(neck)-(CRD) & 1 \\
\hline langerin & $\begin{array}{c}\text { Type II } \\
\text { transmembrane }\end{array}$ & $?$ & (cytoplasmic)-(TM)-(neck)-(CRD) & 1 \\
\hline
\end{tabular}

domains, an $\mathrm{N}$-terminal cysteine rich region, then a collagen like domains, the neck region and a $\mathrm{C}$-terminal CRD. The molecule is a hexamer and resembles the complement protein $\mathrm{Clq}$ (Table I). Serum MBP binds to carbohydrates on microorganisms and facilitates their uptake and clearance and destruction by activation of complement or by direct opsonization for binding to the MBP (77) receptor on phagocytic cells. Early studies by Ezekowitz et al, (78) reported in vitro infection of $\mathrm{H} 9$ lymphoblasts with HIV to be inhibited by human serum MBP. The relevance of this effect of MBP in vivo is seen in individuals who are homozygous for variant MBP alleles. Those with low serum MBP levels were at significantly increased risk of HIV $(79,80)$. Also, the presence of variant MBP alleles was associated with a slower progression to AIDS (81). Furthermore, MBP together with complement is believed to contribute to HIV pathogenesis indirectly by facilitating binding to complement receptor positive cells, e.g. follicular DCs. MBP bridges virions to CD4/CCR5 on the surface of these cells. The mechanism of this enhancement has been reviewed in detail elsewhere $(82,83)$ and are similar to those outlined for the CLRs.

\section{E. CLRs and DC Subsets}

The DC family appears to be the predominant cell type expressing CLR and is able to bind mannose bearing ligands, including HIV gp120. However, other cell types, like endothelial cells can express similar mannose binding CLRs, and interact with HIV like some DC subsets. This review will focus on DC subsets and CLRs $($ see $(84,85)$ for the potential role of CLRs on endothelial cells).

There has been mounting interest and controversy surrounding the role of CLRs expressed by DC in binding HIV. The situation is complicated by the use of a variety of in vitro models and the diversity of DC phenotypes in vitro and in vivo. DC-SIGN was initially reported to play a key role in HIV dis-
ン様領域、ネック領域、C 末端に CRD という 4 つの領域を有す る多量体レクチンである。6 量体を形成し、その構造は補体夕 ンパク質 $\mathrm{C} 1 \mathrm{q}$ に類似している (表 I)。血清中の MBP は微生物 上の糖鎖に結合し、補体の活性化、あるいはこれが直接オプソ ニンとして働いて領食細胞上の MBP 受容体(77)と結合すること により微生物の取り込み、除去と破壊を促進する。Ezekowitz ら の初期の研究から (78)、in vitro での H9 リンパ芽球への HIV の 感染がヒト血清 MBPによって阻害されることが示された。MBP の対立遺伝子がホモになっている個体の検討から、in vivo にお ける MBP の生物学的意義が示されている。血清中の MBP 濃度 が低い個体では HIV 感染の危険性が有意に高かった(79、80)。ま た、複数種の MBP を有する個体では AIDS の進行が遅かった (81)。さらに、補体とMBP が共存すると、これが滤胞樹状細胞 などの補体受容体陽性細胞への結合を促進することにより、間 接的に HIV の感染成立に関与すると考えられている。MBP は これらの細胞上に抢いて CD4/CCR5 とウイルス粒子との橋わた しを行っている。この機構の詳細については既に述べられてい る(82、83)が、C 型レクチン受容体 (CLRs) についても同様のこ とが言える。

\section{E. C 型レクチン受容体と DC 亜集団}

DC の細胞集団は CLR を発現する主要な細胞種であること がわかってきている。この細胞集団は HIV gp120を含むマン ノース含有リガンドに結合することができる。しかしながら、 内皮細胞など他の細胞種も同様のマンノース結合型の CLRs を 発現しており、いくつかの DC 亚集団と同様、HIV と相互作用 する。本総説では DC 亜集団と CLRs に焦点を絞って記述する (内皮細胞の CLRs については他の文献 $(84 、 85)$ 参考のこと)。

HIV の結合における DC 上の CLRs の役割については非常 に興味がもたれており、また議論も多い。in vitro のモデルに 様々な系が用いられていること、 in vitro や in vivo の DC 表現型 が多様であることが話を複雑にしている。DC-SIGNは当初、in vivoに扔けるHIV の感染拡大に重要な役割を果たしていると報 
semination by DC in vivo (86). Although initially suggested to be a DC marker, it is not expressed on the surface of all DC subsets and can be expressed by subsets of macrophage and endothelial cells $(12,72,87,88)$ (Fig. 1). More importantly other CLRs may play a role in HIV attachment to DCs in vivo. In DC, freshly isolated from skin, HIV gp120 binding has been shown to be occur via glycan-CLR binding (12), which directly supports experiments using immature MoDC. However, the CLRs expressed and used by each DC subset for HIV binding is specific, each employing unique combinations of CLRs. For example langerin appears to be the predominant mannose CLR on sessile immature LC that binds HIV gp120. On one dermal DC subset $\left(\mathrm{CD} 1 \mathrm{a}^{++}\right)$it is the MR and on the other dermal DC subset $\left(\mathrm{CD} 14^{+}\right)$it is DC-SIGN in conjunction with MR (Fig. 1). Therefore in vivo, all three CLR, and possibly other unidentified CLR, are involved in gp120 binding. HIV binding to DCs in the skin and mucosa may play a role in viral entry into these cells and transmission between subjects.

Expression of the HIV binding CLRs is regulated and limited to the tissue resident phase of the DC lifecycle (Fig. 1). Lineage negative tonsil and blood DCs, whether CD11 $\mathrm{c}^{+}$(myeloid) or $\mathrm{CD}_{123^{+}}$(lymphoid), do not express mannose binding CLRs and only bind HIV gp120 through CD4 $(12,89,90)$. In addition in skin DCs the CLRs, and their capacity to bind gp120, are down regulated when immature DC migrate from tissue and mature (Fig. 1). The factors controlling this expression are not yet clear but TGF $\beta$ is critical for the expression of langerin and differentiation of Langerhans cells (91) and DC-SIGN depends on IL-4 (92). Whether the expression of CLR on circulating precursor cells determines the migration of differentiating DCs as has been suggested for DC-SIGN (93) or if the expression of CLR occurs during differentiation in situ is not yet clear.

\section{F. Beyond HIV Attachment: The Role of CLRs in DC Infec- tious HIV Entry}

After binding of HIV gp120 to CLRs on immature DC, HIV may enter one of three pathways. Firstly, like soluble gp120 alone, it may enter the endolysosomal pathway resulting in viral degradation and peptide binding to and presentation via MHC II $(69,71)$. For soluble gp120, trafficking to lysosomes in immature MoDCs is obvious after 2 hours (unpublished observations). Similar results are observed with purified HIV virions in immature MoDCs (unpublished observations). A role for CLRs in this process is consistent with the role of the CLR DC-SIGNR in liver, where its abundance may provide the molecular means for microbial clearance of bacteria, bacteriophages, and viruses, including SIV within this organ (94). However, HIV can escape this antigen processing pathway by two mechanisms enhanced by CLR. "Cis," enhanced viral infection of DC and "trans-infection," of T lymphocytes using DC as a conduit. Both processes will be defined and outlined below.
告された(86)。DC-SIGN は最初はDCのマーカー分子といわれ ていたが、すべての DC 亜集団の表面に発現しているわけでは なく、マクロファージの亜集団や内皮細胞にも発現しているこ とがわかった $(12 、 72 、 87 、 88)$ (図 1)。さらに重要なこととして、 in vivo では他の CLRs も HIV のDC への吸着に関与する可能性 がある。皮膚から単離してすぐの DCでは、HIV gp120 との結 合が糖鎖と CLR との結合を介して起こるが(12)、これは未成熟 MoDC を用いた実験の結果を直接支持するものである。しかし ながら、DC が発現するCLRs や HIV との結合に用いられる CLRs はその亜集団によって異なっており、各々の亜集団が独 自の CLRs の組み合わせを用いている。例えば、表皮に定着し た未成熟ランゲルハンス細胞 (LC) においては、HIV gp120に結 合する主要なマンノース結合性レクチンは langerin である。真 皮 DC 亜集団の片方 $\left(\mathrm{CD}^{2} \mathrm{a}^{++}\right)$ではこのレクチンはマンノース受 容体 (MR) にあたり、もう一方の真皮 DC 亜集団 $\left(\mathrm{CD} 14^{+}\right)$では MRに加え DC-SIGN がこの機能を有している(図 1)。したがっ て in vivoにおいては 3 種類の CLR すべてとさらにおそらく他 の未同定の CLR がHIV gp120 との結合に関与している。皮膚や 粘膜に存在する DC と HIV との結合は細胞への侵入と細胞間伝 播に関与するのであろう。

HIV 結合性の CLRs は DC のライフサイクルのうち組織に 常在しているDCにのみ限定して発現されている(図 1)。 lineage negative な扁桃 DC と血中 DC は CD11+(骨髄系) であっても CD123+（リンパ系）であってもともにマンノース結合性 CLRs は発現して㧍らず、CD4 を介してしか HIV gp120 と結合できな い(12、89、90)。さらに皮膚の未成熟 DC が組織から遊走して成 熟 DC になると、CLRs の発現量とその gp120への結合能は低 下する (図 1)。CLRs の発現を制御する因子はまだ明らかでは ないが、 langerinの発現とランゲルハンス細胞の分化には TGF$\beta(91)$ か DC-SIGN の発現にはIL-4 が必要である(92)。DC-SIGN で言われているように循環血中の前駆細胞にCLR が発現するこ とによって DC の遊走先が決定されているのか(93)、あるいは DCが組織で分化する最中にCLRが発現するのかについては明ら かになっていない。

\section{F. HIV の吸着後：DC 感染性の HIV が侵入する際の CLRs の 役割}

未成熟 DC の CLRsに HIV gp120 が結合した後、HIVは 3 通りの侵入経路のうちどれかひとつを介して侵入するようであ る。その 1 つは可溶化型 $\mathrm{gp} 120$ の場合と同様であるが、HIV が エンドリソゾーム経路へ侵入しウイルスの分解、MHC II分子へ のペプチド結合と提示へ移行する経路である(69、71)。可溶化型 gp120 の場合、未成熟 MoDCにおけるリソゾームへの移行は 2 時間後にみられた（未発表）。同じ細胞で同様の結果が精製 HIV を用いた場合にも観察された（未発表）。この過程におけ る CLRs の役割は肝臟のCLRである DC-SIGNR と同様であっ た。肝臓においてこのレクチンが豊富であるのはこの臓器内の バクテリア、バクテリオファージや SIV などのウイルスを除去 するためであろう(94)。しかし、HIV はこのプロセシングの過程 を CLRによって克進される 2 通りの機構によって回避すること ができる。つまり DCへのウイルス感染の “Cis”増強と、DC を経由した Tリンパ球への “trans-infection”感染の 2 つである。 2 つの感染過程についてその定義と概略を以下に示す。 
A

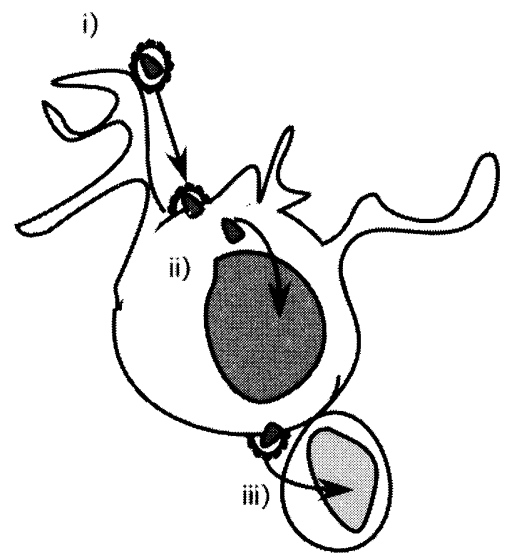

B

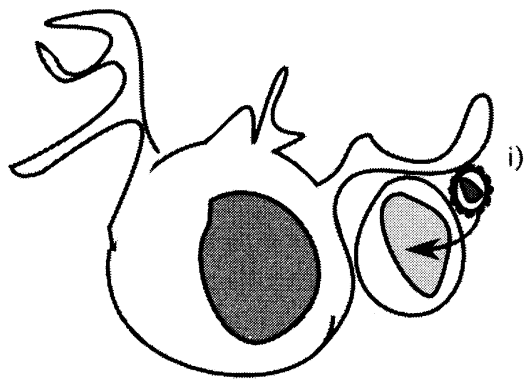

Fig. 2. CL “Cis," versus "trans," mechanisms of CD4+ lymphocyte infection via DCs. A. CL "Cis," enhanced infection of DCs and transfer to CD4 ${ }^{+} T$ lymphocytes. i) High affinity and capacity binding of HIV by CLR increases the probability of CD4/ CCR5 binding. ii) CD4/CCR5 binding results in viral-host membrane fusion and viral-host genome integration. iii) HIV transferred from infected DC to responding CD4+ T lymphocytes. B. CL "Trans" infection from DCs to CD4+ Tlymphocytes. i) High affinity and capacity binding of HIV by CLR and transfer to responding $\mathrm{CD}^{+} \mathrm{T}$ lymphocytes in the absence of DC infection.

\section{F-1. Cis Enhancement of HIV Infection of DCs by CLRs}

As CD4 and chemokine receptors are co-expressed on DC, one mode of HIV-CLR binding and escape is via "Cis enhancement" of HIV infection. In the Cis model, DC-SIGN and DC-SIGNR have been shown to increase the level of infection in transfected cell lines when CD4 and appropriate chemokine receptors are present (95), i.e. attachment via CLRs does not lead to infection per se, but enhances the levels of infectious entry via CD4 (Fig. 2). Interestingly, expression of DC-SIGN in lymphoid cell lines with limiting levels of CCR5 allowed entry and replication of R5 viruses in a CCR5-dependent manner, a property not exhibited by the parental cell lines (95). Therefore when CD4 and/or chemokine receptors are limiting (as in most myeloid DC subsets in Fig. 1), attachment via CLRs may be a pre-requisite for subsequent $\mathrm{CD} 4 /$ chemokine mediated viral fusion. Indeed recently it has been shown that CLR attachment is crucial for CD4 dependent R5 HIV entry in immature MoDC (12), although the level of HIV entry and replication was modest $\left(1,300\right.$ copies of HIV DNA per $10^{5}$ cells). This "Cis," enhancement by CLR on DC must be restricted to only the immature DCs that express CLRs (Fig. 1).

\section{F-2. An Indirect Role of CLRs in Infection of $\mathrm{CD4}^{+} \mathrm{Lym}$ - phocytes via DC: The Trans-Infection Hypothesis}

Geijtenbeek et al, (86), Bashirova et al (84) and Pohlmann et al (85) used transfected cell lines, to show that DC-SIGN and DC-SIGNR may bind virus and transfer it to permissive CD4/ CCR5 cell types, without the need for infection of the transfectants.

It has been known for some time that entry of HIV into immature MoDC, is not a pre-requisite for viral transfer to $\mathrm{CD}^{+}$

\section{F-1. CLRs を介した DC への HIV 感染の Cis 増強}

$\mathrm{CD} 4$ とケモカイン受容体は DC 上に共発現しているので、 HIV-CLR の結合によってウイルス除去機構を回避する方法の 1 つは HIV 感染の “Cis 増強”を介するものである。この Cis モデ ルについては、CD4 と適当なケモカイン受容体を発現する遺伝 子導入細胞に扔いてDC-SIGN と DC-SIGNR の発現が HIV 感染 の頻度を増大させることが示されている(95)。すなわち CLRs を 介した結合はそれ自体では感染を誘導しないが CD4 㖶する ウイルス侵入の頻度を増大させる(図 2)。興味深いことにCCR5 の発現が低いリンパ球系細胞株に DC-SIGNを発現させると、 R5 ウイルスが CCR5 依存的に侵入、複製した。これは親株で は観察されなかった(95)。したがって、CD4またはケモカイン 受容体の発現が限られている時には（図 1 の骨髄系 DC 亜集 団の大部分に相当）、CD4/ケモカインを介したウイルス融合を 起こすためにCLRs を介する結合があらかじめ必要となるので あろう。実際、R5 HIV が CD4 依存的に未成熟 MoDC へ感染す るためには CLR との結合が必要であることが最近示された (12)。但しHIV の侵入と複製の程度はそれほど高くなかった （105個の細胞あたり HIV の DNA が1,300 コピー検出された）。 このCLRによる“Cis”増強は、CLRs を発現する未成熟 DCに 限られているはずである(図 1)。

F-2. DC を介した CD4陽性リンパ球への感染における CLRs の間接的な役割： trans-infection 仮説

Geijtenbeek ら(86)、Bashirova ら(84)、Pohlmann ら(85)は遺 伝子導入細胞を用いて、この細胞上のDC-SIGN や DC-SIGNR が ウイルスに結合LCD4/CCR5 を発現する感受性細胞へのウイル ス感染を仲介すること、その際に細胞のウイルス感染は必要な いことを示した。

以前、CD4陽性リンパ球へ HIV が伝播するのに未成熟 MoDC があらかじめ HIV に感染する必要はないという報告が 
lymphocytes $(31,85,96)$. After the discovery of DC-SIGN on MoDC, it was hypothesized that DC could transfer HIV from exposed DCs to T cells via this lectin. Indeed the concept of DC-SIGN "trans-infection," has recently been demonstrated in MoDC, to account for a part of HIV attachment on DC that later may lead to transfer to $\mathrm{CD}^{+}$lymphocytes independent of HIV infection (97). High DC-SIGN expression is required (98) and this can be induced by IL-4 stimulation (92). However whether trans-infection, mediated by DC-SIGN alone, occurs in vivo is doubtful, as the majority of DC subsets are DC-SIGN negative and on CD14-positive dermal DC, expression appears to be far lower than that observed in MoDC cultures (12). Therefore if "trans-infection," is redefined as viral transfer from DC to T lymphocytes independent of DC infection, DC-SIGN may mediate one of several possible routes.

As the theory of prolonged retention of HIV on the surface of DCs has now been modified to a model of intracellular retention (99), what is the cellular location of HIV in DCs which mediates survival, and transfer to $\mathrm{CD} 4^{+}$lymphocytes? HIV entry into DC after attachment may occur through either: i) viral host cell membrane fusion through CD4/CCR5 as outlined above ii) endocytosis into coated pits or iii) entry into vacuolar caves (Fig. 3). CLRs may enhance each pathway by increasing viral attachment, although binding to CLRs is not an absolute prerequisite for attachment, intracellular uptake and transfer of HIV to T lymphocytes in the DC family. For instance in iii) HIV entry into vacuoles appears to be a particular feature of the mature DC family (100) which have minimal levels of surface CLRs.

Several recent studies of HIV uptake into DC have helped clarify the process of transfer to T cells. An elegant study by Frank et al (100) has demonstrated intact virus particle uptake
あった(31、85、96)。DC-SIGNが MoDCに発現する分子として発 見されてから、DC はこのレクチンを介して HIVを $\mathrm{T}$ 細胞に運 搬することができるのではないかと予想された。HIV が DCに 吸着した後、感染の成立とは独立に CD4 陽性リンパ球へのウイ ルスの運搬を誘導する機構を説明するため、近年、DC-SIGNを 介した “trans-infection”という概念が提示されている(97)。これ には DC-SIGN の高発現が必要であるが(98)、IL-4 刺激でこの発 現を誘導することが可能である(92)。しかし、DC-SIGN のみを 介した trans-infection が in vivo で起きているかどうかは疑わし い。これは DC 亜集団の大多数は DC-SIGN 陰性であり、CD14 陽性真皮 DC の DC-SIGN の発現も MoDC に比べて相当低いた めである(12)。それゆえ “trans-infection”を DC から Tリンパ球 へのウイルス運搬でありDCの感染とは独立の現象であると再定 義するならば、DC-SIGN はいくつかの可能な経路のうちその一 つを仲介しているということなのかもしれない。

HIV がDC の細胞表面で長時間保持されているという説は、 細胞内に保持されているというモデルに一部修正されている (99)。それでは HIV の生存と CD4 陽性リンパ球への運搬を仲介 するDCの細胞内において HIV はどのように局在しているので あろうか。DCへの吸着後に見られる HIV の侵入は：i) CD4/ CCR5 を介した宿主細胞膜との融合（既に概略を示した）、ii） 被覆小孔内へのエンドサイトーシス、あるいは iii) 空胞への侵 入、のいずれかの経路を取るものと思われる(図 3)。CLRs はウ イルスの吸着量を増加させることにより各々の経路を活性化さ せるのかもしれない。といっても DC 細胞種において、ウイル スと CLRs との結合はウイルスの吸着、細胞内取り込み、 $\mathrm{T} リ$ ンパ球への HIV 運搬に絶対に必要とされるものではない。例え ば iii) HIV の空胞への侵入は細胞表面に CLRs をほとんど発現 していない成熟 DC に見られる特別な現象である(100)。

DC 内部への HIV の取り込みについての最近の研究から、 このウイルスが $\mathrm{T}$ 細胞へ運搬される過程が明らかにされてい る。Frankら(100)のエレガントな研究から、自然な状態のウイル i)

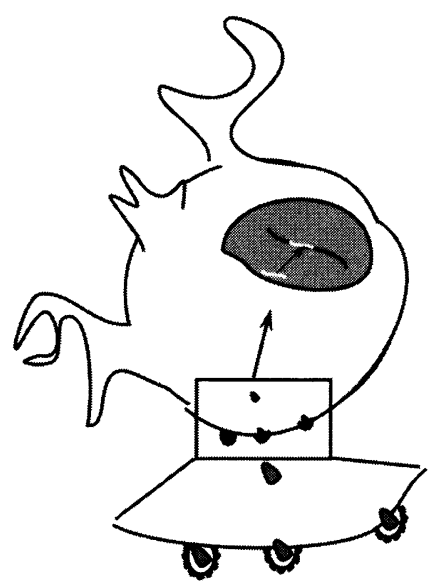

ii)

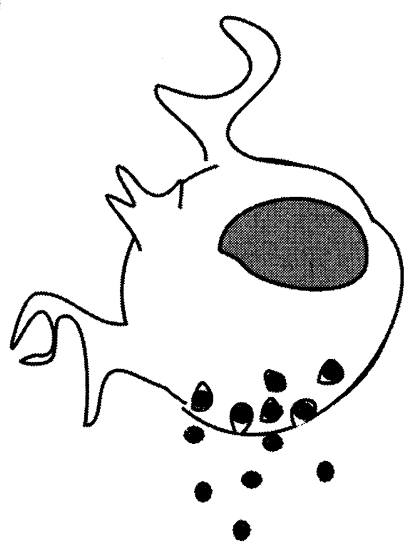

iii)

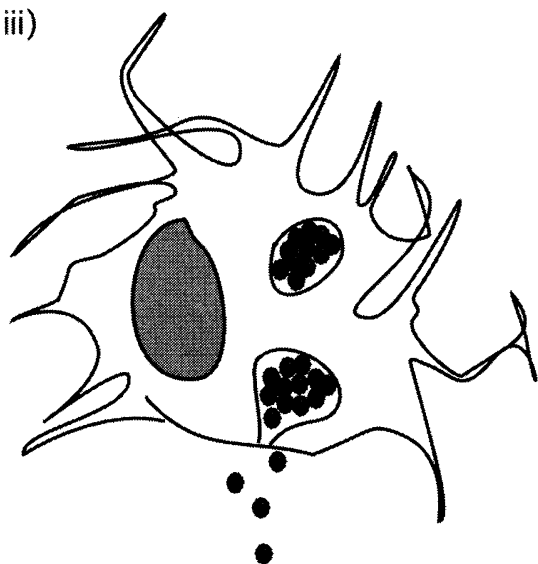

Fig. 3. Modes of HIV entry into DCs. i) CD4/chemokine receptor mediated plasma membrane fusion leading to genomic proviral integration. ii) Endocytosis into coated pits. iii) Uptake through vacuolar "caves". 
into coated pits and retention at the periphery of the endocytically active, immature MoDCs. Thus MR and DC-SIGN could be responsible for uptake in the MoDC model. Whether the CLRs remain attached to the virion during this uptake, remains unknown. We have observed that there is clear segregation of DCSIGN from internalized purified HIV gp120 and virions in immature MoDC (unpublished observations). Although MoDC are clearly the most studied immature DC, several early reports have indeed observed in vivo and ex vivo immature DC to uptake HIV independent of viral fusion. Electron microscopy studies by Rappersberger et al, (24) of LC from mucosal and skin biopsies of infected patients, showed that HIV was located within intracytoplasmic vacuoles. Dusserre et al, (22) also observed engulfed virions within early endosomes of LCs from epidermal skin suspensions, and this may be mediated by langerin and/ or other CLRs (but not by DC-SIGN and MR which are not present on LC; Fig. 1). HIV gp120 uptake by DezutterDambuyant (34), supports this notion as langerin has been associated with Birbeck granule formation (7), and gp120 uptake has been observed with the induction of Birbeck granule formation at the plasma membrane. Thus MR, DC-SIGN and langerin all may be involved in uptake of HIV into coated pits of immature DC independent of CD4/CCR5-mediated fusion. Although binding to such CLRs may facilitate endocytosis, the factors resulting in subsequent viral lysis or survival are unknown.

In mature MoDC, Frank et al, (100) also observed uptake of HIV but it differed in that there was perinuclear localization of HIV in large vacuolar caves deeper within the cell than in immature MoDC (similar to those initially observed by Rappersberger et al, (24) in LC). Large vacuoles are also seen in mature DC emigrants from vaginal tissue sections (101). Partially mature MoDC can have residual levels of DC-SIGN $(86,89)$ and low MR expression, but fully mature emigrant DC do not express either (12). Another difference observed between immature and mature MoDC was the persistence of large number of intact virions only within the latter (100). This suggests that entry into immature MoDC via coated pits leads mainly to viral lysis within lysosomes. Such differences in pathways of virus uptake may underlie the clear difference in HIV transfer to $\mathrm{T}$ cells from MoDCs matured with different stimuli (102).

\section{G. The Great Escape: Mechanisms of Viral Transfer from DC to CD4 ${ }^{+} \mathrm{T}$ Lymphocytes. Support for Viral Fusion as a Pre-Requisite for HIV Transfer:}

HIV attachment to CLR and endocytic entry may not necessarily lead to transfer to a permissive cell type. In transfected CLR models, certain DC-SIGN and DC-SIGNR chimeras were adept at binding virus, but failed to transfer HIV to the permissive cell types (103). The same can be seen in differentially matured MoDC, where residual levels of DC-SIGN are constant, yet some mature DC are not capable of transferring
ス粒子はエンドサイトーシス活性を有する未成熟 MoDCによっ て被覆小孔に取り込まれ、細胞の辺縁部に保持されることがわ かった。したがって、MoDCのモデル系に扔いては MR と DCSIGN がHIV の取り込みに必要なのであろう。取り込み過程に おいて CLRs がウイルス粒子に結合したまま解離しないのかど うかは不明である。我々は未成熟 MoDC 内で DC-SIGN と取り 込まれた精製 HIV gp120 あるいはウイルス粒子が離れて存在し ているという知見を得ている (未発表)。MoDC は最も研究が 進んでいる未成熟 DCではあるが、初期の報告では、未成熟 DC がウイルスの融合なしに HIVを取り込むことが in vivo、ex vivo で実際に観察されている。Rappersbergerらの電子顕微鏡を用い た研究(24)によれば、感染した患者の粘膜および皮膚生検由来の LC 内で、HIV は細胞質内の空胞に存在していた。Dusserreら (22)は上皮組織の懸濁液から取得した LC内で、取り込まれたウ イルス粒子が初期エンドソーム内に存在することを示した。こ の取り込みは langerinもしくはそれ以外の CLRs（ただしLCに 発現していない DC-SIGNやMRによるものではない; 図 1を 参照）を介するものであろう。HIV gp120 の取り込みに関する Dezutter-Dambuyant の研究(35)はこの知見を支持するものであ る。彼によれば langerin は Birbeck 顆粒の形成に関与しており (7)、gp120 の取り込みは形質膜における Birbeck 顆粒が形成さ れるのに伴って観察される。以上より MR、DC-SIGN、langerin はすべて未成熟 DC の被覆小孔への HIV 取り达みに関与する可 能性がある。これは CD4/CCR5を介した融合とは独立のもので ある。このCLRsに対するウイルスの結合はエンドサイトーシス を促進すると考えられるが、その後のウイルス溶解もしくはウ イルス生存を決定する因子は不明である。

Frank ら (100)は成熟 MoDC 内への HIVの取り込みを観察し ているが、未成熟 DC の場合とは異なり、HIV はさらに細胞内 部の核周辺部の大空胞内に局在していた（同様の結果は以前に Rappersberger らによって LCでも認められていた(24)）。㓐組 織移植片から遊走してきた成熟 DC の内部にも大空胞が確認さ れている(101)。部分的に成熟した MoDC はDC-SIGNを弱く(86、 89)、MRを低レベルで発現しているが、完全に成熟した遊走DC ではどちらも発現していなかった(12)。未成熟 MoDC と成熟 MoDC で観察されるもうひとつの相違点は、後者でのみ完全な ウイルス粒子が持続的に多数産生されることである(100)。これ は被覆小孔を介して未成熟 MoDC に侵入したウイルスがほとん どリソゾーム内で溶解されることを示唆している。異なる刺激 を受けて成熟した MoDCでは T 細胞へのHIV運搬の程度に明ら かな違いが見られるが、これはウイルス取り込み経路の違いに よるものであろう(102)。

G. 大いなる回避：DC から CD4 陽性Tリンパ球へのウイルス 伝播機構. HIV 伝播にあらかじめウイルス融合が必要である証 拠

HIV がCLR に結合しエンドサイトーシス系を介して侵入 することは感受性細胞への伝播に必ずしも必要ではない。CLR を遺伝子導入したモデルにおいて DC-SIGN と DC-SIGNRのキ メラタンパク質はウイルスに結合したが、感受性細胞へ HIV を 運搬することができなかった(103)。同様の結果が成熟 DCでも 観察された。すなわちDC-SIGN の発現は一定であるにもかかわ らず、成熟 DC の中にはウイルスの運搬ができないものがあっ 
virus (102). Although the fate of most virions after entry into DCs is to lysosomes, some appear to escape via an alternate pathway. By analogy, in brain microvascular endothelial cells (which express CLR seen on some DC subsets (87)) after 16 hours post HIV exposure, most virion-containing vesicles fused with primary lysosomes, where the virions were degraded (104). However some virions remained intact in occasional vesicles that did not fuse with lysosomes (104). These vesicles were similar in size and location to those seen in immature MoDC (100).

As outlined previously, the pivotal role of DC in the immune response involves two phases of DC differentiation: immature DC take up antigen and mature DC transport processed antigen to lymph nodes and contact responding $\mathrm{CD}^{+}$lymphocytes. However studies of HIV infection with immature MoDC and subsequent co-culture with $\mathrm{CD} 4^{+}$lymphocytes do not necessarily resemble all aspects of the complex migratory and phenotypic changes associated with the movement of DC from peripheral tissue to the draining lymph nodes.
た(102)。DCに侵入したウイルス粒子のほとんどはリソゾーム に行く運命であるが、別の経路を介してこれを回避するものも ある。同様に、HIV 感染 16 時間後の脳微小血管内皮細胞（DC 亜集団の一部と同じCLR を発現している(87)）では、ウイルス 粒子を含む小胞のほとんどは一次リソゾームと融合しており、 そこではウイルス粒子は分解されていた(104)。しかし、リソ ゾームと融合していない一時的な小胞の内部には完全なウイル ス粒子が分解されずに残っていたものもあった(104)。これらの 小胞は未成熟 MoDC で観察されたものと大きさや局在が似てい た $(100)$ 。

先に概略を示したように、免疫応答におけるDCの重要な 役割はその 2 つ分化段階で果たされている。すなわち未成熟 DC による抗原取り込みと、成熟 DC によるプロセシングされ た抗原のリンパ節への輸送ならびに反応性 CD4 陽性リンパ球と の接触である。未成熟 MoDCに $\mathrm{HIV}$ を感染させてその後 CD4 陽性リンパ球と共培養する実験が行われているが、これは末梢 組織から所属リンパ節への DC の移動に伴って起こる遊走性や 表現型の複雑な变化のすべてを模倣する実験系ではない。

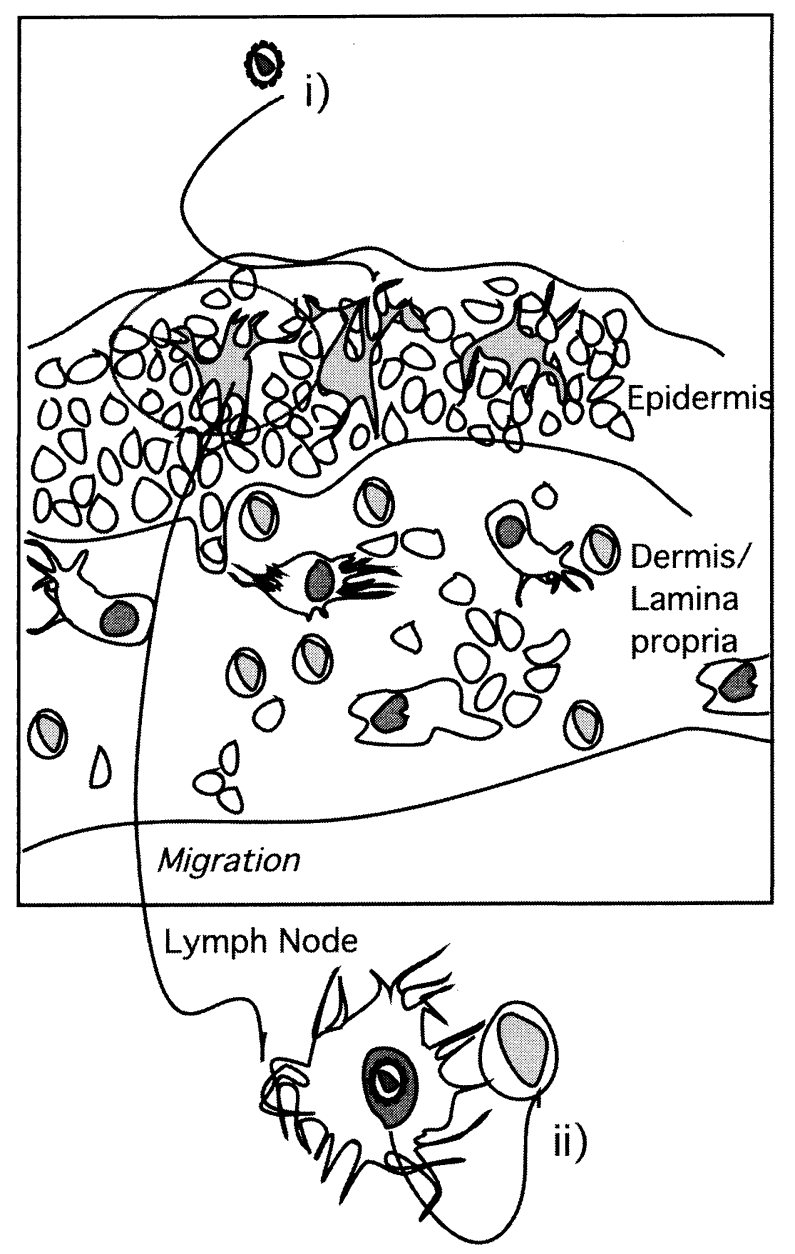

Fig. 4. Proposed model for "Cis," enhancement of DC infection by CLR for in situ and in vivo HIV transmission. *Squamous epithelia only represented in this model. i) "Cis," enhancement of CD4 dependent viral entry into DC through CLR. ii) Lack of CLR expression and CLR-lysosomal degradation limits DC-HIV "trans-infection," of CD4 ${ }^{+} \mathrm{T}$ cells. Selection of R5 isolates occurs via CD4/CCR5-restricted expression. 
Other in vitro models are more useful. These involving in situ infection of DC in epidermal skin blisters or abraded skin sheets (epidermis and dermis) are able to address the issues of migration and maturation after DC are exposed to HIV. They simulate the initial stages of migration and maturation of DC from tissue to the draining lymph node. In such models, viral entry by fusion was observed to be a pre-requisite for viral transfer to $\mathrm{CD}^{+}{ }^{+}$lymphocytes as this could only occur in LCs with R5 isolates (47) as shown by specific inhibition by a CCR5 antagonist AOP-RANTES (40). Although less than $1 \%$ of LCs were infected, subsequent exposure to $\mathrm{CD} 4^{+}$lymphocytes produced microgram/ml quantities of HIV p24, indicative of explosive viral replication (40). These data show that the role of langerin and/or other LC CLRs on LCs maybe restricted to a "Cis," enhancing CD4/CCR5 dependent role in HIV infectious entry, as CLRs cannot discriminate between X4 and R5 isolates or be inhibited by CCR5 antagonists (Fig. 4). Alternatively retention of endocytically resident HIV may be lost or subsequently trafficked to other functional compartments where proteolysis and MHC II loading occur.

In models of in situ infection of dermal and lamina propria tissue $\mathrm{DC}\left(\mathrm{CD} 1 \mathrm{a}^{+}\right.$and $\mathrm{CD} 14^{+}$immature $\left.\mathrm{DC}\right)$, the mechanisms of transfer to $\mathrm{CD}^{+}$lymphocytes are not yet as clear. In skin explants dermal DC transferred R5 isolates with greater efficiency than X4 HIV isolates (47), yet it is unclear whether viral fusion was a pre-requisite for viral transfer. However in studies by Pope et al, (45) skin DC emigrants (epidermis and dermis) indicated that initial viral replication in $\mathrm{DC}$ was required for subsequent transfer to $\mathrm{CD} 4^{+}$lymphocytes. Evidence of $d e$ novo viral production and active budding from $\mathrm{DC}$ into the $\mathrm{DC}$ $\mathrm{T}$ cell junction is quite effectively shown in electron micrographs in a study by Hladik and colleagues (101). Therefore dermal/ lamina propria DC may also follow the same pattern of HIV transfer as LCs. Thus viral fusion and infection may establish stable long-term reservoirs for transfer to $\mathrm{CD}^{+}$cells (Fig. 4B). The alternative is survival of HIV within a vesicular compartment prior to transfer to $\mathrm{CD}^{+}$lymphocytes. In vivo transmission studies show a genotypic selection bottleneck which allows the transmission and persistence of such R5 isolates in early stages of disease $(57,105)$, consistent with selection of R5 strains within DCs. Furthermore, individuals who are homozygous for a 32 base pair deletion in CCR5 are highly resistant to HIV-1 transmission (105). Thus these tissue DC models, or animal models, may be much more instructive about initial HIV infection of skin/mucosal DCs in vivo than the more convenient MoDC and CLR THP-1 transfectant models.

\section{H. Conclusion}

The interaction of HIV with DC differs from the conventional infection pathway observed in $\mathrm{CD}^{+}$lymphocytes. HIV has subverted a normal DC mechanism for antigen transport to
MoDC以外の in vitro モデルも有用である。表皮に水泡を形 成させたものやはがれた皮虐シート（表皮と真皮）の中に存在 する DC に in situでウイルスを感染させるなどの方法により、 DC が HIV に曝された後の細胞の遊走や成熟の機構を研究対象 にすることが可能となる。このモデルは組織から所属リンパ節 へ移動する DCについて、その遊走や成熟の初期段階を再現す るものである。このモデルを用い、CD4 陽性リンパ球へのウイ ルス伝播に先立ち、融合による DCへのウイルス侵入があらか じめ必要であるということが示された。これは R5 株に感染し た LCにのみ観察されるものであり (47)、CCR5の拮抗剤である AOP-RANTES によって特異的に阻害された(40)。感染したLCは 1 \%以下であったが、これを CD4 陽性リンパ球に曝すると、 $\mathrm{mg} / \mathrm{ml}$ レベルの HIV p24 が産生された。これは爆発的なウイル ス複製を示している(40)。このデー夕は LC 上の langerin もしく は他の LC CLRs が“Cis”増強にのみ関与していること、つまり HIV 感染の侵入の際にこれらが CD4/CCR5 依存性のウイルス侵 入機構を増強することを示すものである。というのは CLRsは X4 株と R5 株を区別できず、またその結合は CCR5 拮抗剤で阻 害されないはずだからである (図 4)。そうでなければ、エンド サイトーシスにより取り込まれた HIV は除去されるか、タンパ ク質分解や MHC II 分子への積載をする機能部位へ移動してし まうであろう。

真皮や粘膜固有層の組織に存在するDC $\left(\mathrm{CD}^{2} \mathrm{a}^{+}\right.$未成熟 $\mathrm{DC}$ と CD14+未成熟 DC) への in situ感染モデルでは、CD4陽性のリン パ球へウイルスを伝播する機構は未だ明らかではない。皮虐外 移植片の真皮 DC は HIV X4 株よりも R5 株を効率よく運搬す る(47)が、この際ウイルス融合が必要であるかどうかは不明であ る。しかし Popeら(45)の研究によれば、皮膚（表皮と真皮）か ら遊走した DC では CD4 陽性リンパ球へウイルスを運搬するた めにDC 内でのウイルス複製があらかじめ必要であった。Hladik とその共同研究者の電子顕微鏡による観察により、DC内部で新 たに生じるウイルス複製や DC 内部から $\mathrm{DC}$ と $\mathrm{T}$ 細胞の接触部 に向けて能動的にウイルスが出芽する証拠が示されている (101)。したがって真皮や粘膜固有層の DC もLC と同様の方法 でHIV を運搬するのであろう。このようにウイルス融合と感染 によって、CD4 細胞へウイルスを伝播するための安定な貯蔵庫 が長期にわたって確立される (図 4B)。もう一つの考え方はHIV がCD4 陽性リンパ球へ運搬されるまで小胞内で生き残っている というものである。in vivo の伝播実験から、疾患初期に R5 株 の伝播と感染の持続を許容するような遺伝的な選択機構がある ことがわかった(57、105)。これは DC 内部で R5 株が選択される ことと一致する。さらに、32 塩基対欠損型の CCR5 のみの対立 遺伝子をもつヒトは HIV-1 感染に対して極めて抵抗性である (105)。ここで述べた組織 DC モデルや動物モデルは、これより 簡便な MoDC や CLR 遺伝子を THP-1 に導入するモデルよりも、 in vivo における皮虐・粘膜 DCへの HIV 初期感染についてより 有益な情報をもたらすであろう。

\section{H. 結 語}

HIV と DC の相互作用は、今まで言われてきた CD4 陽性リ ンパ球への感染経路とは異なるものである。HIVはリンパ節へ 抗原を輸送するという正常な DC の機能を崩壊させ、DCから 
lymph nodes and transfer to CD4+ lymphocytes. Given HIV appears to benefit from the very mechanisms skin DCs use to bind pathogens by their distinct saccharides. As DC subsets in different tissue locations have different repertoires of surface molecules, it is not surprising HIV binds to diverse CLRs which differ on each DC subset. In immature skin DCs the CLRs langerin, DC-SIGN and MR represent newly defined HIV binding receptors. As these skin DC mature, there is a transition to predominant binding via CD4, the type of binding observed in lineage negative blood and tonsil DC. The role of CLRs appears to be as a mechanism for concentrating HIV on the surface of DC (like heparan sulfate for herpes simplex virus) and then facilitating HIV fusion through CD4/CCR5, which may lead to transfer to T cells. Viral uptake by immature DC may also occur by endocytosis and result in a "dead-end," through lysosomal degradation, although there is another pathway observed in MoDC that leads to retention of intact virions. Further studies need to determine the subsequent events that lead to release of such virions and whether in fact this occurs in peripheral DC in vivo.

To conclude DC expressing CLR are at the mucosal site of first contact with HIV. The CLRs, langerin, DC-SIGN and MR may indeed represent new targets for antiretroviral therapy or prophylaxis. However such "blocking," strategies would need to employ multiple compounds to inhibit HIV envelope binding to all three CLRs, CD4 and the chemokine receptors CCR5 and to a lesser degree, CXCR4.
CD4 陽性リンパ球へと伝播する。HIV は皮膚の DC が特定の糖 鎖によって病原体と結合する、まさにその機構を利用している のである。異なる組織に存在する DC 亜集団は異なるレパート リーの表面分子を有しているので、HIV が各々の DC 亜集団上 の様々な異なるCLRsに結合しても不思議ではない。皮膚の未 成熟 DCにおいては、langerin、DC-SIGNや MRのような CLRs が新たにHIV 結合性受容体として定義されるようになった。こ れらの皮虐 DC が成熟するとCD4を介した結合が優先的になる ように変化する。これは、 lineage negative の血中 DC や扁桃 DC で観察された結合様式と同様である。CLRs の役割はDC表面上 にHIVを濃縮することであり(これは単純へルペスウイルスに 対するヘパラン硫酸の役割と同様である）、これが CD4/CCR5 を介した HIV 融合を可能にし、さらにこれがT細胞へのウイ ルス運搬を誘導する。MoDCで見出された完全なウイルス粒子 を細胞に保持するという別経路もあるが、ウイルスがエンドサ イトーシスによって未成熟 DCに取り込まれてしまうと、これ はリソゾームでの分解という“行き止まり”で終わる。ウイルス 粒子の放出を誘導する現象について、またin vivoの末梢 DC 内 部でこのようなウイルス放出が実際に起きるかどうかについて 確定させるためにはさらに研究が必要である。

最後になるが、CLR 発現 DC はHIV の最初の接触部位 である粘膜に存在している。したがって langerin、DC-SIGN、 MR といった CLRs は実際に抗レトロウイルス治療あるいは予 防の新しい標的となりうる。但し、そのような “blocking”戦略 をとる場合は、複数の化合物を用いることによって、3 種類の CLRs、CD4、ケモカイン受容体 CCR5 と、それより寄与は低い がCXCR4 に対する HIV エンベロープの結合をすべて阻害する 必要があるだろう。

\section{東京大学大学院·薬学系研究科}

加藤 健太郎 訳

\section{References}

1. Steinman, R. M. (1991) Annu. Rev. Immunol. 9, 271-296

2. Banchereau, J., and Steinman, R. M. (1998) Nature 392, 245-252

3. Hart, D. N. (1997) Blood 90, 3245-3287

4. Robinson, S. P., Patterson, S., English, N., Davies, D., Knight, S. C., and Reid, C. D. (1999) Eur. J. Immunol.29, 2769-2778

5. Katz, S. I., Tamaki, K., and Sachs, D. H. (1979) Nature 282(5736), 324-326

6. Stingl, G., Romani, N., and Wolff, K. (1987) Adv. Dermatol. 2, 269-281

7. Valladeau, J., Ravel, O., Dezutter-Dambuyant, C., Moore, K., Kleijmeer, M., Liu, Y., Duvert-Frances, V., Vincent, C., Schmitt, D., Davoust, J., Caux, C., Lebecque, S., and Saeland, S. (2000) Immunity 12, 71-81

8. Bell, D., Young, J. W., and Banchereau, J. (1999) Adv. Immunol. 72, 255-324

9. Lenz, A., Heine, M., Schuler, G., and Romani, N. (1993) J. Clin. Invest. 92, 2587-2596

10. Nestle, F. O., Zheng, X. G., Thompson, C. B., Turka, L. A., and Nickoloff, B. J. (1993) J. Immunol. 151, 6535-6545

11. McLellan, A. D., Heiser, A., Sorg, R. V., Fearnley, D. B., and Hart, D. N. (1998) J. Invest. Dermatol. 111, 841-849

12. Turville, S. G., Cameron, P. U., Handley, A., Lin, G., Pohlmann, S., Doms, R. W., and Cunningham, A. L. (2002) Nature Immunology 3, 975-983

13. Romani, N., Gruner, S., Brang, D., Kampgen, E., Lenz, A., Trockenbacher, B., Konwalinka, G., Fritsch, P. O., Steinman, R. M., and Schuler, G. (1994) J. Exp. Med. 180, 83-93

14. Sallusto, F., and Lanzavecchia, A. (1994) J. Exp. Med. 179, 1109-1118

15. Mehlhop, E., Villamide, L. A., Frank, I., Gettie, A., Santisteban, C., Messmer, D., Ignatius, R., Lifson, J. D., and Pope, M. (2002) J. Immunol. Methods 260, 219-234

16. Lukas, M., Stossel, H., Hefel, L., Imamura, S., Fritsch, P., Sepp, N. T., Schuler, G., and Romani, N. (1996) J. Invest. Dermatol. 106, 12931299

17. Steinman, R., Hoffman, L., and Pope, M. (1995) J. Invest. Dermatol. 105(1 Suppl.), 2S-7S

18. Hu, J., Gardner, M. B., and Miller, C. J. (2000) J. Virol. 74, 6087-95

19. Spira, A. I., Marx, P. A., Patterson, B. K., Mahoney, J., Koup, R. A., Wolinsky, S. M., and Ho, D. D. (1996) J. Exp. Med. 183, 215-25

20. Bhoopat, L., Eiangleng, L., Rugpao, S., Frankel, S. S., Weissman, D., Lekawanvijit, S., Petchjom, S., Thorner, P., and Bhoopat, T. (2001) Mod. Pathol. 14, 1263-1269 
21. Cimarelli, A., Zambruno, G., Marconi, A., Girolomoni, G., Bertazzoni, U., and Giannetti, A. (1994) J. Acquir. Immune Defic. Syndr. 7, $230-235$

22. Dusserre, N., Dezutter-Dambuyant, C., Mallet, F., Delorme, P., Philit, F., Ebersold, A., Desgranges, C., Thivolet, J., and Schmitt, D. (1992) J. Invest. Dermatol. 99, 99S-102S

23. Giannetti, A., Zambruno, G., Cimarelli, A., Marconi, A., Negroni, M., Girolomoni, G., and Bertazzoni, U. (1993) J. Acquir. Immune Defic. Syndr. 6, 329-333

24. Rappersberger, K., Gartner, S., Schenk, P., Stingl, G., Groh, V., Tschachler, E., Mann, D. L., Wolff, K., Konrad, K., and Popovic, M. (1988) Intervirology 29, 185-94

25. Tschachler, E., Groh, V., Popovic, M., Mann, D. L., Konrad, K., Safai, B., Eron, L., diMarzo Veronese, F., Wolff, K., and Stingl, G. (1987) J. Invest. Dermatol. 88, 233-7

26. Zambruno, G., Mori, L., Marconi, A., Mongiardo, N., De Rienzo, B., Bertazzoni, U., and Giannetti, A. (1991) J. Invest. Dermatol. 96, 97982

27. Frankel, S. S., Tenner-Racz, K., Racz, P., Wenig, B. M., Hansen, C. H., Heffner, D., Nelson, A. M., Pope, M., and Steinman, R. M. (1997) Am. J. Pathol. 151, 89-96

28. Frankel, S. S., Wenig, B. M., Burke, A. P., Mannan, P., Thompson, L. D., Abbondanzo, S. L., Nelson, A. M., Pope, M., and Steinman, R. M. (1996) Science 272, 115-117

29. Cameron, P. U., Freudenthal, P. S., Barker, J. M., Gezelter, S., Inaba, K., and Steinman, R. M. (1992) Science 257, 383-387

30. Pope, M., Betjes, M. G., Romani, N., Hirmand, H., Cameron, P. U., Hoffman, L., Gezelter, S., Schuler, G., and Steinman, R. M. (1994) Cell 78, 389-398

31. Blauvelt, A., Asada, H., Saville, M. W., Klaus-Kovtun, V., Altman, D. J., Yarchoan, R., and Katz, S. I. (1997) J. Clin. Invest. 100, 2043-2053

32. Cameron, P. U., Lowe, M. G., Sotzik, F., Coughlan, A. F., Crowe, S. M., and Shortman, K. (1995) Adv. Exp. Med. Biol. 378, 429-433

33. Delorme, P., Dezutter-Dambuyant, C., Ebersold, A., Desgranges, C., Thivolet, J., and Schmitt, D. (1993) Res. Virol. 144, 53-58

34. Dezutter-Dambuyant, C. (1995) Adv. Exp. Med. Biol 378, 447-451

35. Granelli-Piperno, A., Delgado, E., Finkel, V., Paxton, W., and Steinman, R. M. (1998) J. Virol. 72, 2733-2737

36. Granelli-Piperno, A., Finkel, V., Delgado, E., and Steinman, R. M. (1999) Curr. Biol. 9, 21-29

37. Granelli-Piperno, A., Moser, B., Pope, M., Chen, D., Wei, Y., Isdell, F., O’Doherty, U., Paxton, W., Koup, R., Mojsov, S., Bhardwaj, N., Clark-Lewis, I., Baggiolini, M., and Steinman, R. M. (1996) J. Exp. Med. 184, 2433-2438

38. Hu, J., Miller, C. J., O’Doherty, U., Marx, P. A., and Pope, M. (1999) AIDS Res. Hum. Retroviruses 15, 1305-1314

39. Hu, J., Pope, M., Brown, C., O’Doherty, U., and Miller, C. J. (1998) Lab. Invest. 78, 435-451

40. Kawamura, T., Cohen, S. S., Borris, D. L., Aquilino, E. A., Glushakova, S., Margolis, L. B., Orenstein, J. M., Offord, R. E., Neurath, A. R., and Blauvelt, A. (2000) J. Exp. Med. 192, 1491-500

41. Knight, S. C. (1994) AIDS Res. Hum. Retroviruses 10, 1591-1592

42. Patterson, S., Rae, A., Hockey, N., Gilmour, J., and Gotch, F. (2001) J. Virol. 75, 6710-6713

43. Patterson, S., Roberts, M. S., English, N. R., Macatonia, S. E., Gompels, M. N., Pinching, A. J., and Knight, S. C. (1994) Res. Virol. 145, 171-176

44. Patterson, S., Robinson, S. P., English, N. R., and Knight, S. C. (1999) Immunol. Lett. 66, 111-116

45. Pope, M., Gezelter, S., Gallo, N., Hoffman, L., and Steinman, R. M. (1995) J. Exp. Med. 182, 2045-2056

46. Pope, M., Ho, D. D., Moore, J. P., Weber, J., Dittmar, M. T., and Weiss, R. A. (1997) Science 278(5339), 786-788

47. Reece, J. C., Handley, A. J., Anstee, E. J., Morrison, W. A., Crowe, S. M., and Cameron, P. U. (1998) J. Exp. Med. 187, 1623-1631

48. Zaitseva, M., Blauvelt, A., Lee, S., Lapham, C. K., Klaus-Kovtun, V., Mostowski, H., Manischewitz, J., and Golding, H. (1997) Nat. Med. 3, 1369-1375

49. Zoeteweij, J. P., and Blauvelt, A. (1998) J. Biomed. Sci. 5, 253-259

50. Greene, W. C., and Peterlin, B. M. (2002) Nat. Med. 8, 673-680

51. Chan, D. C., Fass, D., Berger, J. M., and Kim, P. S. (1997) Cell 89, 263-273

52. Lu, M., Blacklow, S. C., and Kim, P. S. (1995) Nat. Struct. Biol. 2, 1075-1082

53. Alkhatib, G., Combadiere, C., Broder, C. C., Feng, Y., Kennedy, P. E., Murphy, P. M., and Berger, E. A. (1996) Science 272, 1955-1958

54. Dragic, T., Litwin, V., Allaway, G. P., Martin, S. R., Huang, Y., Nagashima, K. A., Cayanan, C., Maddon, P. J., Koup, R. A., Moore, J. P., and Paxton, W. A. (1996) Nature 381, 667-673

55. Feng, Y., Broder, C. C., Kennedy, P. E., and Berger, E. A. (1996) Science 272, 872-877

56. Berger, E. A., Doms, R. W., Fenyo, E. M., Korber, B. T., Littman, D. R., Moore, J. P., Sattentau, Q. J., Schuitemaker, H., Sodroski, J., and Weiss, R. A. (1998) Nature 391(6664), 240

57. Zhu, T., Mo, H., Wang, N., Nam, D. S., Cao, Y., Koup, R. A., and Ho, D. D. (1993) Science 261, 1179-1181

58. Scarlatti, G., Tresoldi, E., Bjorndal, A., Fredriksson, R., Colognesi, C., Deng, H. K., Malnati, M. S., Plebani, A., Siccardi, A. G., Littman, D. R., Fenyo, E. M., and Lusso, P. (1997) Nat. Med. 3, 1259-1265

59. Bakri, Y., Schiffer, C., Zennou, V., Charneau, P., Kahn, E., Benjouad, A., Gluckman, J. C., and Canque, B. (2001) J. Immunol. 166, 37803788

60. Baribaud, F., Pohlmann, S., and Doms, R. W. (2001) Virology 286, 1-6

61. Ugolini, S., Mondor, I., and Sattentau, Q. J. (1999) Trends Microbiol. 7, 144-149

62. Leonard, C. K., Spellman, M. W., Riddle, L., Harris, R. J., Thomas, J. N., and Gregory, T. J. (1990) J. Biol. Chem. 265, 10373-10382

63. Reitter, J. N., Means, R. E., and Desrosiers, R. C. (1998) Nat. Med. 4, 679-684

64. Zhu, X., Borchers, C., Bienstock, R. J., and Tomer, K. B. (2000) Biochemistry 39, 11194-11204

65. Liedtke, S., Adamski, M., Geyer, R., Pfutzner, A., Rubsamen-Waigmann, H., and Geyer, H. (1994) Glycobiology 4, $477-484$

66. Lin, G., Baribaud, F., Ni, H., Haggarty, B., Pöhlmann, S., Weissman, D., Hoxie, J. A., and Doms, R. W. (2002) Submitted for publication,

67. Willey, R. L., Shibata, R., Freed, E. O., Cho, M. W., and Martin, M. A. (1996) J. Virol. 70, 6431-6436

68. Feinberg, H., Mitchell, D. A., Drickamer, K., and Weis, W. I. (2001) Science 294(5549), 2163-6

69. Sallusto, F., Cella, M., Danieli, C., and Lanzavecchia, A. (1995) J. Exp. Med. 182(2), 389-400

70. Stahl, P. D., and Ezekowitz, R. A. (1998) Curr. Opin. Immunol. 10, 50-55

71. Engering, A., Geijtenbeek, T. B., van Vliet, S. J., Wijers, M., van Liempt, E., Demaurex, N., Lanzavecchia, A., Fransen, J., Figdor, C. G., 
Piguet, V., and van Kooyk, Y. (2002) J. Immunol. 168, 2118-2126

72. Soilleux, E. J., Morris, L. S., Leslie, G., Chehimi, J., Luo, Q., Levroney, E., Trowsdale, J., Montaner, L. J., Doms, R. W., Weissman, D., Coleman, N., and Lee, B. (2002) J. Leukoc. Biol. 71, 445-457

73. Curtis, B. M., Scharnowske, S., and Watson, A. J. (1992) Proc. Natl. Acad. Sci. U S A 89, 8356-8360

74. Geijtenbeek, T. B., van Vliet, S. J., van Duijnhoven, G. C., Figdor, C. G., and van Kooyk, Y. (2001) Placenta 22, S19-S23

75. Larkin, M., Childs, R. A., Matthews, T. J., Thiel, S., Mizuochi, T., Lawson, A. M., Savill, J. S., Haslett, C., Diaz, R., and Feizi, T. (1989) Aids 3, 793-798

76. Milone, M. C., and Fitzgerald-Bocarsly, P. (1998) J. Immunol. 161, 2391-2399

77. Fraser, I. P., Koziel, H., and Ezekowitz, R. A. (1998) Semin. Immunol. 10, 363-372

78. Ezekowitz, R. A., Kuhlman, M., Groopman, J. E., and Byrn, R. A. (1989) J. Exp. Med. 169(1), 185-196

79. Garred, P., Richter, C., Andersen, A. B., Madsen, H. O., Mtoni, I., Svejgaard, A., and Shao, J. (1997) Scand J. Immunol. 46, 204-208

80. Pastinen, T., Liitsola, K., Niini, P., Salminen, M., and Syvanen, A. C. (1998) AIDS Res. Hum. Retroviruses 14, 695-698

81. Maas, J., de Roda Husman, A. M., Brouwer, M., Krol, A., Coutinho, R., Keet, I., van Leeuwen, R., and Schuitemaker, H. (1998) Aids 12, 2275-2280

82. Kacani, L., Stoiber, H., Speth, C., Banki, Z., Tenner-Racz, K., Racz, P., and Dierich, M. P. (2001) Mol. Immunol. 38, 241-247

83. Stoiber, H., Kacani, L., Speth, C., Wurzner, R., and Dierich, M. P. (2001) Immunol. Rev. 180, 168-176

84. Bashirova, A. A., Geijtenbeek, T. B., van Duijnhoven, G. C., van Vliet, S. J., Eilering, J. B., Martin, M. P., Wu, L., Martin, T. D., Viebig, N., Knolle, P. A., KewalRamani, V. N., van Kooyk, Y., and Carrington, M. (2001) J. Exp. Med. 193, 671-678

85. Pohlmann, S., Soilleux, E. J., Baribaud, F., Leslie, G. J., Morris, L. S., Trowsdale, J., Lee, B., Coleman, N., and Doms, R. W. (2001) Proc. Natl. Acad. Sci. U S A 98, 2670-2675

86. Geijtenbeek, T. B., Kwon, D. S., Torensma, R., van Vliet, S. J., van Duijnhoven, G. C., Middel, J., Cornelissen, I. L., Nottet, H. S., KewalRamani, V. N., Littman, D. R., Figdor, C. G., and van Kooyk, Y. (2000) Cell 100, 587-597

87. Mukhtar, M., Harley, S., Chen, P., BouHamdan, M., Patel, C., Acheampong, E., and Pomerantz, R. J. (2002) Virology 297, 78-88

88. Soilleux, E. J., Morris, L. S., Rushbrook, S., Lee, B., and Coleman, N. (2002) Hum. Pathol. 33, 652-659

89. Turville, S. G., Arthos, J., Mac Donald, K., Lynch, G., Naif, H., Clark, G., Hart, D., and Cunningham, A. L. (2001) Blood 98, 2482-2488

90. Turville, S. G., Cameron, P. U., Arthos, J., MacDonald, K., Clark, G., Hart, D., and Cunningham, A. L. (2001) J. Clin. Virol. 22, 229-239

91. Geissmann, F., Prost, C., Monnet, J. P., Dy, M., Brousse, N., and Hermine, O. (1998) J. Exp. Med. 187, 961-966

92. Relloso, M., Puig-Kroger, A., Pello, O. M., Rodriguez-Fernandez, J. L., de la Rosa, G., Longo, N., Navarro, J., Munoz-Fernandez, M. A., Sanchez-Mateos, P., and Corbi, A. L. (2002) J. Immunol. 168, 2634-2643

93. Geijtenbeek, T. B. H., Krooshoop, D. J. E. B., Bleijs, D. A., van Vliet, S. J., van Duijnhoven, G. C. F., Grabovsky, V., Alon, R., Figdor, C. G., and van Kooyk, Y. (2000) Nature Immunology 1, 353-357

94. Zhang, L., Dailey, P. J., Gettie, A., Blanchard, J., and Ho, D. D. (2002) J. Virol. 76, 5271-5273

95. Lee, B., Leslie, G., Soilleux, E., O’Doherty, U., Baik, S., Levroney, E., Flummerfelt, K., Swiggard, W., Coleman, N., Malim, M., and Doms, R. W. (2001) J. Virol. 75, 12028-12038

96. Dybul, M., Weissman, D., Rubbert, A., Machado, E., Cohn, M., Ehler, L., O’Callahan, M., Mizell, S., and Fauci, A. S. (1998) AIDS Res. Hum. Retroviruses 14, 1109-1113

97. Wu, L., Martin, T. D., Vazeux, R., Unutmaz, D., and KewalRamani, V. N. (2002) J. Virol. 76, 5905-5914

98. Pohlmann, S., Baribaud, F., Lee, B., Leslie, G. J., Sanchez, M. D., Hiebenthal-Millow, K., Munch, J., Kirchhoff, F., and Doms, R. W. (2001) J. Virol. 75, 4664-72

99. Kwon, D. S., Gregorio, G., Bitton, N., Hendrickson, W. A., and Littman, D. R. (2002) Immunity 16, 135-144

100. Frank, I., Piatak, M., Jr., Stoessel, H., Romani, N., Bonnyay, D., Lifson, J. D., and Pope, M. (2002) J. Virol.76, 2936-2951

101. Hladik, F., Lentz, G., Akridge, R. E., Peterson, G., Kelley, H., McElroy, A., and McElrath, M. J. (1999) J. Virol. 73, 5833-5842

102. Sanders, R. W., De Jong, E. C., Baldwin, C. E., Schuitemaker, J. H., Kapsenberg, M. L., and Berkhout, B. (2002) J. Virol. 76, 7812-21

103. Pohlmann, S., Leslie, G. J., Edwards, T. G., Macfarlan, T., Reeves, J. D., Hiebenthal-Millow, K., Kirchhoff, F., Baribaud, F., and Doms, R. W. (2001) J. Virol. 75, 10523-10526

104. Liu, N. Q., Lossinsky, A. S., Popik, W., Li, X., Gujuluva, C., Kriederman, B., Roberts, J., Pushkarsky, T., Bukrinsky, M., Witte, M., Weinand, M., and Fiala, M. (2002) J. Virol.76, 6689-700

105. Liu, R., Paxton, W. A., Choe, S., Ceradini, D., Martin, S. R., Horuk, R., MacDonald, M. E., Stuhlmann, H., Koup, R. A., and Landau, N. R. (1996) Cell 86, 367-77

Received on August 16, 2002, accepted on September 12, 2002 


\section{Profile of the Authors}

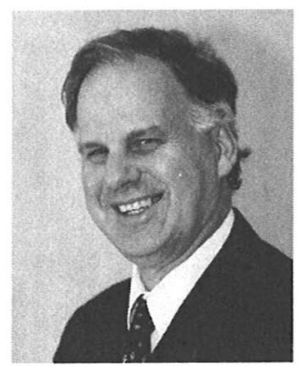

Anthony Cunningham completed his undergraduate training MBBS, B.Med.Sci. in 1972, and subsequently an MD in infectious disease in 1980. From 1981-1983 he was an Australian NHMRC Applied Health Sciences Fellow at the Division of Infectious Diseases, Stanford University, USA. From 1984 to 1996 he was Director of the Virology Department (State Reference Laboratory of Virology) of the Institute of Clinical Pathology and Medical Research, consultant physician in the Infectious Disease Unit at Westmead Hospital and Associate Professor of Virology/Medicine in the University of Sydney, Department of Medicine. In 2000 he was appointed Deputy Director and in 2002 Co-ordinator/Director of the Australian National Centre of HIV Virology Research. In 1996 he was appointed inaugural director of the Westmead Millennium Institute and Professor of Research Medicine, University of Sydney. He has longstanding research interests in the pathogenesis, treatment and prevention of HIV and herpesviruses.

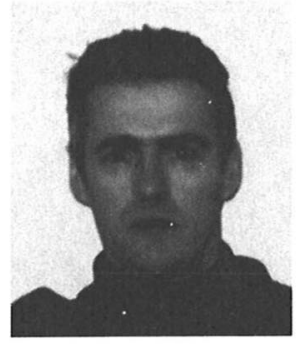

Paul Cameron graduated in medicine with a BMedSci from the University of Western Australia in 1979, trained in immunology specialty then completed his $\mathrm{PhD}$ in the same University in 1992. He then took up positions as Research Associate at the Rockefeller University in New York, an Australian Commonwealth AIDS Research Grant Postdoctoral Fellowship at the Macfarlane Burnet Institute in Melbourne, an RD Wright Fellow at the same Institute and then a CR Roper Research Fellow at the Department of Microbiology and Immunology, University of Melbourne. He has longstanding interests in the interaction of HIV with dendritic cells.

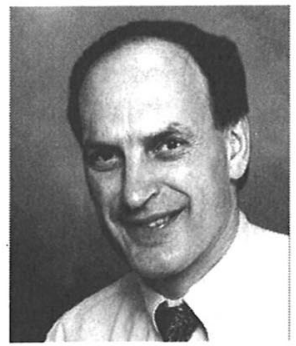

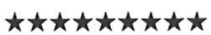

Derek Hart graduated from the University of Otago in 1975 and went as a Rhodes Scholar to Oxford University. He discovered the interstitial dendritic cell as part of his D.Phil studies and this began a passionate interest in dendritic cells and basic cell biology. He is currently the Director of the Mater Medical Research Institute where he also heads the Dendritic Cell Laboratory, which has a large molecular program. He is also chair of the Dendritic Cell Section of the 7th and 8th International Leucocyte Differentiation antigen Workshop.

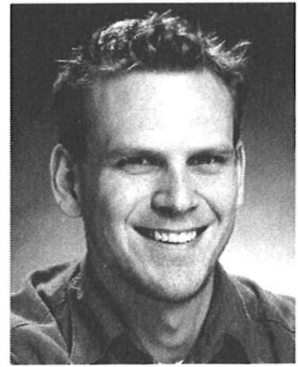

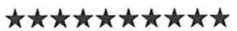

Stuart Turville is currently completing a $\mathrm{PhD}$ in Medicine at the Westmead Millennium Institute, University of Sydney under the supervision of Professor Anthony Cunningham and Dr.Paul Cameron. In 1998 was awarded honours in science and was awarded an Australian Postgraduate award for studies involving HIV attachment to human dendritic cells. Scheduled in January of 2003 to be employed as a Postdoctoral Fellow, Gladstone Institute of Virology and Immunology, San Francisco, CA. 